Biochim Biophys Acta. 2018 April ; 1864(4 Pt B): 1220-1231. doi:10.1016/j.bbadis.2017.06.024.

\title{
Pathobiology of biliary epithelia
}

\author{
Angela C. Cheung, Maria J. Lorenzo Pisarello, and Nicholas F. LaRusso* \\ Division of Gastroenterology and Hepatology, Mayo Clinic Center for Cell Signaling in \\ Gastroenterology, Mayo Clinic, Rochester, MN, United States
}

\section{Abstract}

Cholangiocytes are epithelial cells that line the intra- and extrahepatic biliary tree. They serve predominantly to mediate the content of luminal biliary fluid, which is controlled via numerous signaling pathways influenced by endogenous (e.g., bile acids, nucleotides, hormones, neurotransmitters) and exogenous (e.g., microbes/microbial products, drugs etc.) molecules. When injured, cholangiocytes undergo apoptosis/lysis, repair and proliferation. They also become senescent, a form of cell cycle arrest, which may prevent propagation of injury and/or malignant transformation. Senescent cholangiocytes can undergo further transformation to a senescenceassociated secretory phenotype (SASP), where they begin secreting pro-inflammatory and profibrotic signals that may contribute to disease initiation and progression. These and other concepts related to cholangiocyte pathobiology will be reviewed herein. This article is part of a Special Issue entitled: Cholangiocytes in Health and Disease edited by Jesus Banales, Marco Marzioni, Nicholas LaRusso and Peter Jansen.

\section{Keywords}

Apoptosis; Bile; Cholangiocytes; Cholangiopathies; Proliferation; Senescence

\section{Introduction}

Cholangiocytes are now recognized to play an active role in both homeostatic and pathologic pathways. Disruption of normal cholangiocyte function can lead to the development of one of the "cholangiopathies", a diverse collection of chronic liver diseases that are generally chronic, progressive, often lack effective treatment and may be life threatening (Table 1) $[1,2]$.

In this review, we provide an overview of normal cholangiocyte physiology and function, with selective attention to cholangiocyte dysfunction. In particular, the focus of this article

\footnotetext{
This article is part of a Special Issue entitled: Cholangiocytes in Health and Disease edited by Jesus Banales, Marco Marzioni, Nicholas LaRusso and Peter Jansen.

*Corresponding author at: Mayo Clinic, 200 First Street SW, Rochester, MN 55905, United States.

Transparency document

The Transparency document associated with this article can be found, in online version.

The authors have no conflicts of interest relevant to this manuscript.
} 
will center on mechanisms of secretion and absorption, as well as apoptosis, proliferation, fibrosis, and senescence.

\section{The anatomy of the biliary tree}

Cholangiocytes constitute only $3-5 \%$ of the total population of nucleated cells in the liver, but have a unique morphology depending on their anatomic location within the biliary tree $[3,4]$. Distal to the canals of Hering, which are lined by both cholangiocytes and hepatocytes, the biliary tree coalesces into different levels of intrahepatic ducts, which include small bile ductules/terminal cholangioles (diameter $<15 \mu \mathrm{m}$ ), interlobular ducts (15$100 \mu \mathrm{m})$, septal ducts $(100-300 \mu \mathrm{m})$, area ducts $(300-400 \mu \mathrm{m})$, segmental ducts $(400-800$ $\mu \mathrm{m})$ and the right and left hepatic ducts $(>800 \mu \mathrm{m})$ [5]. These converge to form the extrahepatic ducts, which are comprised of the common hepatic duct, cystic duct and the common bile duct [5,6]. In rodents, small (diameter $<15 \mu \mathrm{m})$ and large $(>15 \mu \mathrm{m})$ bile ducts are lined by small and large cholangiocytes, respectively [7-9]. In humans, a corollary is believed to exist, but no clear-cut size distinction between "small", "medium" and "large" cholangiocytes is apparent. In both species, however, both small and large bile ducts are lined with increasing numbers of cholangiocytes, with smaller ducts circumferentially lined by 4 to 5 cholangiocytes (rodents and humans), and larger ducts lined by 8 to 15 cholangiocytes in rodents and up to 40 cholangiocytes in humans [9-12]. Embryologically, intrahepatic cholangiocytes and hepatocytes are both believed to be derived from hepatoblasts [13], while extrahepatic cholangiocytes originate from the endoderm, much like the pancreas and duodenum [14]. This developmental divergence may explain some of the functional differences between extra- and intrahepatic cholangiocytes.

Together with the portal vein and hepatic artery, the biliary tree forms the portal triad, which defines the basic architectural unit of the liver, the lobule [15]. The lobule consists of rows of hepatocytes lined by sinusoids which drain into a central vein. The arterial supply of the biliary tree is provided by the peribiliary vascular plexus, a network of small branches which emerge from the hepatic artery [16]. Blood then flows into branches of the portal vein, or directly into the hepatic sinusoids [16].

In addition to the classic trio of vascular and biliary structures, the portal triad also consists of adrenergic and cholinergic nerves. The large, medium, and septal intrahepatic bile ducts and the surrounding peribiliary glands appear to be well innervated, in contrast to the interlobular ducts and bile ductules, with some nerves intimately associated with the endothelium [17]. Aminergic (releasing tyrosine hydroxylase), peptidergic (releasing neuropeptide $\mathrm{Y}$, substance $\mathrm{P}$, vasoactive intestinal polypeptide [VIP], calcitonin gene-related peptide or galanin) and cholinergic (releasing acetylcholine) sympathetic and parasympathetic nerve fibers have been observed in close proximity to bile ducts [18]. Neuropeptide Y-positive nerves have also been associated with extrahepatic ducts, and may regulate the flow of bile through autocrine and/or paracrine mechanisms $[19,20]$.

Finally, the portal triad is also associated with lymphatics. The hepatic lymphatic system is extensive, comprising as much as $50 \%$ of total lymphatic flow [21]. Lymph flows from the

Biochim Biophys Acta. Author manuscript; available in PMC 2018 July 01. 
space of Disse to lymphatic capillaries around the portal triads, then enters the liver parenchyma, closely associating with arterial branches [21].

\section{Normal cholangiocyte structure and function}

Cholangiocytes are highly polarized structures, with an apical (luminal) and a basolateral plasma membrane [22]. This polarity is established by the zonula occludens, tight junctions located near the apical membrane [22]. The surface of the apical membrane is characterized by microvilli, which increase the available surface area by five-fold, and a primary cilium, which responds to mechanical, osmolar and chemical stimuli and controls critical pathways that maintain cholangiocyte homeostasis $[4,22,23]$. Intracellularly, the actin cytoskeleton provides directionality of vesicular trafficking and maintains the polarity, distribution and functional activity of plasma membrane proteins [24,25].

Communication with neighboring and distant targets is achieved through a number of mechanisms, including endocytosis and exocytosis. While receptor-mediated endocytosis likely occurs at both the apical and basolateral domains, given the presence of coated pits and vesicles at both surfaces, some data suggest that exocytosis may be specific to the apical membrane $[22,24,26,27]$. Multivesicular bodies are located at the apical domain, where they have the ability to fuse either with apical lysosomes or the plasma membrane, allowing their contents to undergo degradation or secretion into the bile duct lumen, respectively [27]. While the exact role of the vesicles released in this manner remains somewhat unclear, these small (30-100 nm) extracellular vesicles may play a key role in cell-cell communication by transporting proteins, lipids, messenger RNA (mRNA) and microRNAs (miRNA) to local or distant targets [28]. Communication between neighboring cells is further enhanced by the gap junctions between each cholangiocyte, which allow for direct cytoplasmic communication [29].

There is also functional heterogeneity between small and large cholangiocytes, which give rise to functional differences in secretory, absorptive, apoptotic and proliferative ability. These will be further described below and are summarized in Table 2 [12,30-34].

\subsection{Secretory and absorptive functions}

Classically, it is believed that large intrahepatic cholangiocytes, rather than small cholangiocytes, are responsible for secreting bile. Large cholangiocytes are thought to produce the majority of bile, while the rest $(10-30 \%)$ is produced by the hepatocytes in rats and humans respectively [35,36]. However, it has been demonstrated that both small and large cholangiocytes express bile acid transporters (e.g., sodium/taurocholate co-transporting polypeptide [ntcp], organic anion-transporting polypeptide [oatp1] and multidrug resistance protein $2[m r p 2])$ and aquaporins, suggesting that both may play a substantive role in bile acid transport and production [37,38]. Regardless, it is clear that the apical and basolateral membranes of large cholangiocytes possess specialized functions via the presence of different ion carriers and channels (Fig. 1A and B).

On the apical domain, proteins are tailored to enable both secretory $\left(\mathrm{HCO}_{3}{ }^{-}, \mathrm{Cl}^{-}\right.$, water) and absorptive functions (bile acids, glucose, amino acids, water). Bicarbonate is the main 
secretory product of the cholangiocytes and functions to regulate $\mathrm{pH}$ for activation of pancreatic enzymes and to facilitate the absorption of lipophilic organic acids. $\mathrm{HCO}_{3}{ }^{-}$ secretion occurs via the $\mathrm{Cl}^{-} / \mathrm{HCO}_{3}{ }^{-}$exchanger (anion exchanger 2 [AE2]) [39]. It is driven by intracellular $\mathrm{pH}$ as well as the $\mathrm{Cl}^{-}$concentration gradient thought to be generated primarily by the excretion of $\mathrm{Cl}^{-}$through the low conductance cystic fibrosis transmembrane conductance regulator (CFTR) [40]. However, a more recent hypothesis centers around the ability of CFTR to regulate ATP release, which then activates inositol 1,4,5-triphosphate receptor $\left(\mathrm{IP}_{3} \mathrm{R}\right)$ via apical $\mathrm{P} 2 \mathrm{Y}$ nucleotide receptors, thereby causing the release of $\mathrm{Ca}^{2+}$ from the endoplasmic reticulum [41]. $\mathrm{Cl}^{-}$secretion is then thought to be mediated by a $\mathrm{Ca}^{2+}$-dependent $\mathrm{Cl}^{-}$and a $\mathrm{Ca}^{2+}$ - and cAMP-independent high conductance $\mathrm{Cl}^{-}$channel $[42,43]$. The apical membrane also contains $\mathrm{K}^{+}$channels $\left(\mathrm{a} \mathrm{Ca}^{2+}\right.$-activated small conductance [SK2] $\mathrm{K}^{+}$channel and a $\mathrm{Ca}^{2+}$-activated intermediate-conductance $\mathrm{K}^{+}$channel-1 [IK-1]) and a $\mathrm{Na}^{+}-\mathrm{HCO}_{3}{ }^{-}$cotransporter (mice only) [44,45].

The apical membrane also allows for reabsorption of $\mathrm{Na}^{+}$(through NHE2 and NHE3), glucose (through the $\mathrm{Na}^{+}$-dependent glucose transporter [SGLT1]), glutamate (through the glumate transporter), bile acids (through the ileal bile acid transporter [iBAT] and apical sodium-dependent bile acid transporter [ASBT]) and water (through aquaporin-1 [AQP-1]) [46-51].

On the basolateral domain, $\mathrm{HCO}_{3}{ }^{-}$enters the cell via the $\mathrm{Na}^{+}$-dependent $\mathrm{Cl}^{-} / \mathrm{HCO}_{3}{ }^{-}$ exchanger $\left(\mathrm{Na}^{+}: \mathrm{HCO}_{3}{ }^{-}\right.$symporter in rodents), with the $\mathrm{Na}^{+}$concentration gradient achieved via the $\mathrm{Na}^{+} / \mathrm{H}^{+}$exchanger isoform 1 (NHE1) [46,52]. The membrane potential is determined by $\mathrm{K}^{+}$channels $\left(\mathrm{Ca}^{2+}\right.$-activated small conductance [SK2] $\mathrm{K}^{+}$channel and intermediateconductance $\mathrm{Ca}^{2+}$-activated $\mathrm{K}^{+}$channel-1 [IK-1]) and $\mathrm{Cl}^{-}$is actively transported into the cell via the $\mathrm{Na}^{+} / \mathrm{K}^{+} / 2 \mathrm{Cl}^{-}$cotransporter $[44,53-55]$. A Na${ }^{+}$gradient created by a $\mathrm{Na}^{+} / \mathrm{K}^{+}-$ ATPase provides energy for the transport of solutes [56].

Reabsorption of substrates released into the biliary lumen is hypothesized to permit the modulation of osmolarity and bile acid concentration in bile [57]. These include the uptake of conjugated bile acids from the apical domain which occurs via the apical sodiumdependent bile acid transporter (ASBT), and the reabsorption of glucose (which likely modulates osmolarity both through the uptake of glucose and $\mathrm{Na}^{+}$, but also via the influx of water molecules), which occurs via the sodium dependent glucose transporter (SGLT1) [50,58]. Absorption of glutamate via the glutamate transporter allows for the recycling of glutathione, which is critically important as it forms a significant component of hepatocyte, bile-salt independent bile flow, being an osmotically active substance, as well as a major element of hepatic detoxification [59]. Luminal glutathione is metabolized by $\gamma$ glutamyltranspeptidase into glutamate and a cysteine and glycine dipeptide, which are then reabsorbed via the glutamate transporter and dipeptide transporter respectively $[60,61]$. Water is also absorbed via AQP1 and $\mathrm{Na}^{+}$via NHE2 and NHE3 [46,47].

Secretion of $\mathrm{HCO}_{3}{ }^{-}$and $\mathrm{Cl}^{-}$into the bile duct lumen is controlled through constitutive endocrine, neuronal and paracrine pathways [62]. Secretion is principally stimulated by secretin, whose receptors are located on large, but not small cholangiocytes [63]. Secretin 
binds to a G-protein-coupled receptor and stimulates a cAMP/protein kinase A (PKA)dependent pathway which in turn activates the apical channels outlined above.

Secretion can also be driven by neuropeptide VIP, neurotransmitter bombesin as well as corticosteroids. Both VIP and bombesin act via cAMP signaling, with bombesin also inducing secretion via cAMP-independent methods such as cGMP, $\mathrm{Ca}^{2+}$ and microtubuleindependent mechanisms [64,65]. In rat cholangiocytes, exposure to corticosteroids, dexamethasone or budesonide leads to biliary bicarbonate secretion due to upregulation of apical $\mathrm{Cl}^{-} / \mathrm{HCO}_{3}{ }^{-}$exchanger and basolateral $\mathrm{Na}^{+} / \mathrm{H}^{+}$exchanger (NHE1) [66].

Both parasympathetic and sympathetic stimuli are also important for the regulation of biliary secretion. Acetylcholine release secondary to vagal stimulation potentiates $\mathrm{HCO}_{3}{ }^{-}$secretion through binding to $\mathrm{M}_{3}$ muscarinic receptors on the basolateral membrane. Basal paracrine factors that are released into bile include ATP, which binds to the $\mathrm{P}_{2} \mathrm{Y}_{12}$ purinergic receptor and activates apical $\mathrm{Cl}^{-}$secretion (through $\mathrm{Ca}^{2+}$-activated $\mathrm{Cl}^{-}$channels as outlined above) and basolateral $\mathrm{HCO}_{3}{ }^{-}$influx (through NHE1), which in turn potentiates $\mathrm{HCO}_{3}{ }^{-}$secretion $[67,68]$. Rat cholangiocytes and a human cholangiocarcinoma cell line express both $a-$ and $\beta$-adrenergic receptors [69]. Stimulation of adrenergic receptors potentiates secretin-induced biliary flow and $\mathrm{HCO}_{3}{ }^{-}$secretion through a $\mathrm{Ca}^{2+}$ - and PKC-dependent augmentation of the cAMP signaling pathway [69].

Inhibition of ductal secretion is controlled by a number of factors including somatostatin, gastrin, dopaminergic agonists, endothelin and gamma-aminobutyric acid (GABA).

Somatostatin acts directly by inhibiting secretin-stimulated bicarbonate and fluid secretion, and through disruption of cholangiocyte fluid absorption through an unknown mechanism [70,71]. Gastrin acts via both gastrin and cholecystokinin-B, inducing expression of $\mathrm{PKCa}$, $\mathrm{PKC} \beta 1$ and $\mathrm{PKC} \beta 2$ and inhibiting cAMP production [72]. Rat cholangiocytes express dopaminergic receptors on their basolateral surface [73]. Activation of these receptors leads to an increase in intracellular $\mathrm{IP}_{3}$ and $\mathrm{Ca}^{2+}$, thereby inhibiting secretin-stimulated secretion [73]. Rat cholangiocytes also express endothelin and GABA receptors, which inhibit secretin-induced cholangiocyte secretion via inhibition of adenylyl cyclase and cAMP levels/Cl- efflux respectively [74].

Lastly, cholangiocytes express a number of proteins whose local function is unknown. This includes pancreatic and salivary alpha-amylase, pancreatic lipase and trypsin, all of which are primarily expressed in both small and large cholangiocytes, specifically large ducts, septal ducts and peribiliary glands [32]. Conversely, only small cholangiocytes express blood group antigen and Bcl-2, an anti-apoptotic protein, and only large cholangiocytes express cytochrome P4502E1 [30,31,33].

\section{The role of primary cilia in homeostasis and pathology}

Primary cilia are located on both small and large cholangiocytes, and consist of an axoneme (9 pairs of microtubules around a central core), which emerges from a basal body which is derived from a centriole [23]. Cholangiocyte cilia have critical mechano-, osmo- and chemosensory functions (Fig. 2), and their disruption has been hypothesized to lead to 
certain cholangiopathies, such as autosomal dominant polycystic kidney disease (ADPKD), which can lead to cystic liver and kidney disease [23].

Their mechanosensory function is enabled through polycystin-1 (PC-1, a cell surface mechanoreceptor) and polycystin-2 (PC-2, a Ca ${ }^{2+}$ channel) [75]. As cilia are moved by fluid flowing through the bile duct lumen, intracellular $\mathrm{Ca}^{2+}$ increases, which then inhibits cAMP levels in cholangiocytes via adenylyl cyclase 6 [75].

Similarly, cholangiocytes can respond to changes in bile osmolality through mediation of intracellular $\mathrm{Ca}^{2+}$ via the Transient receptor potential vaniloid 4 (TRPV4) channel, which then leads to changes in intracellular ATP release [76]. TRPV4 is inhibited in settings of hypertonicity and activated by hypotonicity. In the setting of a hypotonic luminal milieu, $\mathrm{Ca}^{2+}$ shifts from the extracellular to the intracellular space [76]. Additionally, ATP is released, which then leads to the secretion of $\mathrm{HCO}_{3}{ }^{-}$, suggesting that the osmosensory function of cilia is integral in regulating bile formation and composition [76].

Lastly, the chemosensory function of cholangiocyte cilia are thought to stem from the presence of specific, yet ubiquitous receptors. These include somatostatin receptor 3 and a serotonin receptor, which have been found on primary cilia of other cell types such as fibroblasts and chondrocytes [77-79]. Cholangiocytes also contain $\mathrm{P}_{2} \mathrm{Y}_{12}$, a receptor whose ligands are nucleotides (e.g., ATP and ADP). Activation of $\mathrm{P}_{2} \mathrm{Y}_{12}$ increases intracellular cAMP levels which can then activate a number of cAMP-dependent pathways such as those involving adenylyl cyclase, PKA and a protein called "exchange protein activated by cAMP" (EPAC) $[41,75]$. Bile acids can also influence cholangiocyte fluid secretion through TGR5, a bile acid receptor located on cholangiocyte cilia, as well as multiple proteins in the nuclear and apical membranes [80]. Activation of TGR5 by bile acids leads to inhibition of adenylyl cyclase, thereby reducing cAMP-dependent cholangiocyte secretion [81].

The functional implications of the mechano-, osmo- and chemosensory functions of cilia have yet to be completed elucidated. It is hypothesized, however, that bile flow may be pulsatile and may have variable tonicity, to which cilia have the ability to respond by modulating the intracellular and extracellular milieu, including biliary fluid composition [23].

It is known that defects in cilia can cause a number of diseases, such as ADPKD, which is caused by mutations in the genes PKD1 or PKD2 (these encode PC-1 and PC-2 respectively) [23]. Abnormal cilia appear to cause a decrease in $\mathrm{Ca}^{2+}$ and an increase in cAMP, which then lead to aberrant cholangiocyte proliferation, functional changes to the surrounding cellmatrix and fluid secretion as well as absorption by cholangiocytes [23]. Together, these changes result in cystogenesis, though the precise mechanism for these pathogenic pathways remains to be completed outlined [23].

Ciliary defects have also been implicated in cholangiocarcinoma. Both chemical and mechanical deciliation of normal human and rat cholangiocytes induces proliferation, while mechanical deciliation has the additive effect of increasing anchorage-independent growth, a phenotypic characteristic of tumors, as well as cellular invasion [82,83]. Deciliation also induces mitogen-activated protein kinase (MAPK) and Hedgehog (Hh) signaling, two 
pathways involved in the development of cholangiocarcinoma [83]. Overexpression of HDAC6 in normal cholangiocytes leads to deciliation, both of which are seen in cholangiocarcinoma [83]. Restoration of cilia in cholangiocarcinoma cells by HDAC6 suppression results in decreased in proliferation as well as anchorage-dependent growth [83].

\section{The role of miRNA in cholangiocyte homeostasis and pathology}

MiRNAs are a class of non-coding RNAs that can regulate gene expression in a posttranscriptional manner by binding to complementary sites on mRNA [84]. mRNA that is targeted in this manner is either suppressed or degraded [84]. miRNAs are numerous, and can modify a myriad of processes from development and differentiation to proliferation, and have also been demonstrated to have a role in cholangiopathies (summarized in Table 4) $[84,85]$.

The flow and composition of bile has multiple impacts on cholangiocyte function, from influencing ciliary response pathways to altering proliferation (discussed further below). There is evidence that one of the key regulators of bile acid synthesis and secretion is miR-33a. MiR-33a arises from an intronic region in the gene that encodes for Sterol regulatory element-binding protein (SREBP)-2, and appears to coordinate pathways that control bile acid and cholesterol metabolism [86,87]. MiR-33a can silence ATP-binding cassette transporter $\mathrm{A} 1$ (ABCA1) and ABCG1, which are induced by the ligand-activated transcription factor, Liver X Receptor (LXR) and whose activation can lead to cholesterol efflux from peripheral tissues and enterocytes [88]. MiR-33a can also suppress ATP8B1, a canalicular phospholipid flippase which maintains hepatic secretory function by stabilizing membrane polarity, and ABCB11, which encodes the bile salt export protein (BSEP), responsible for canalicular bile export [89]. It has also been demonstrated that CYP7A1, the rate-limiting step of bile acid synthesis, activates SREBP-2, which simultaneously induces miR-33a expression [87]. Activation of miR-33a then leads to a negative feedback loop which inhibits CYP7A1 [87].

MiR-144 also decreases gene expression of ABCA1, and is mediated by two transcription factors of the nuclear receptor family, the aforementioned LXR and the Farnesoid X Receptor (FXR) [90,91]. Both FXR and LXR activation increase levels of miR-144, which leads to suppression of ABCA1 [90,91]. In turn, this leads to decreased plasma HDL and decreased cholesterol efflux from macrophages [90,91].

Additional miRNAs that have been implicated in cholesterol metabolism and bile acid homestasis include miR-122, miR-422a, miR-133. MiR-122 is highly conserved, and is the most abundant liver miRNA (comprising 70\% of all miRNA) [92]. It has a myriad of roles in hepatic homeostasis, including control of bile acid synthesis through silencing of CYP7A1 [93]. MiR-422a also silences CYP7A1, thereby providing another pathway to mediate bile acid homeostasis [93].

MiRNAs also appear to coordinate inflammatory cytokine responses both in homeostasis as well as to microbial exposure. For example, one of the key components of $\mathrm{T}$ cell

Biochim Biophys Acta. Author manuscript; available in PMC 2018 July 01. 
homeostasis is B7-H1, whose translation is suppressed by miR-513 in resting cholangiocytes [94]. IFN- $\gamma$ stimulation significantly decreases miR-513 expression and inhibition of miR-513 activity leads to B7-H1 protein expression which then triggers apoptosis [94]. Given that higher levels of proinflammatory cytokine responses with molecules such as tumor necrosis factor (TNF)- $\alpha$ and IFN- $\gamma$ are associated with primary biliary cholangitis (PBC), primary sclerosing cholangitis (PSC) and biliary atresia, aberrant B7-H1 expression may play a key role in these pathologies [95-97].

In human cholangiocytes, cytokine signaling in response to microbial exposure can be mediated by miR-98 and let-7 [98]. These miRNAs repress the translation of the cytokineinducible Src homology 2-containing protein (CIS), a regulator of cytokine signaling [98]. Stimulation of cholangiocytes with lipopolysaccharide (LPS) or infection with Cryptosporidium parvum leads to downregulation of miR-98 and let-7 and subsequent expression of CIS, which results in increased nuclear factor kappa-light-chain enhancer of activated B cells (NF- $\kappa B$ ) levels [98].

A number of miRNAs have been associated with cholestasis and specific cholangiopathies. The role of miR-21 in cholestasis and fibrosis has been investigated in vitro (murine biliary and human hepatic stellate cell [HSC] lines) and in vivo (bile duct ligated [BDL] mice, a model of obstructive cholestasis) [99]. In both settings, inhibition of miR-21 leads to decreased proliferation and fibrosis. In addition, cell lines demonstrate increased apoptosis, while BDL mice have decreased HSC activation and increased expression of the protein, small mothers against decapentaplegic (Smad)-7 [99]. The latter can inhibit both cellular proliferation and fibrosis and is a direct target for miR-21, and thus may be driving the downstream effects of miR-21 [100].

In PBC, miR-506 has been shown to be overexpressed in the intrahepatic bile ducts of patients with PBC as compared to normal and PSC controls [101]. Furthermore, miR-506 can bind specifically to the 3'UTR region of the mRNA for AE2, preventing protein expression [101]. Induction of miR-506 in cultured PBC cholangiocytes leads to decreased AE2 activity, which is abrogated with miR-506 inhibition [101].

MiRNA levels have also been studied in PSC as well as an animal model of PSC, multi-drug resistance gene-2 knockout ( $\mathrm{Mdr}^{-/-}$) mice. $\mathrm{Mdr} 2^{-/-}$mice have decreased expression of miR-24 at 66 weeks compared to 12 weeks, and a corresponding increase in MEN1 expression with increasing age [102]. Moreover, patients with late stage PSC have increased MEN1 expression compared to controls with early disease [102]. MiR-24 can target a complementary site on MEN1, and it has been shown that increasing MEN1 correlates with increasing expression of fibrosis genes (e.g., fibronectin 1, collagen type 1 a 1 , tumor growth factor $\beta 1$ and $\alpha$-smooth muscle actin) $[102,103]$. Menin, the protein product of MEN1, which itself is a tumor suppressor gene, may thus be responsible for mediating the cholangiocyte response cholangiocytes to injury [102].

MiR-7 (miR-7-a-1 and miR-7-a-2) may also play a substantive role in cholangiocyte proliferation and fibrosis, and susceptibility to injury. It is hypothesized that miR-7 plays a role in modulating the neurogenin-3 (Ngn-3) pathway, which is aberrantly expressed in 
tissues of subjects with PSC, as well as experimental models of cholestasis and sclerosing cholangitis [104]. MiR-7 is upregulated in settings of cholangiocyte proliferation and can suppress exedin-3-stimulated proliferation by inhibiting the promitotic effects of Ngn-3 [104]. In addition, Ngn-3 silencing results in virtually absent miR-7 levels despite exposure of normal rat cholangiocytes to exedin-4, compared to cells with intact Ngn-3, demonstrating that miR-7 synthesis is also dependent on Ngn-3 [104].

Investigation of miRNA levels in biliary atresia has demonstrated that miRNAs may influence AKT signaling pathways, which can induce hepatic stem cell activation. The suppression of mRNA targets (e.g., friend of GATA [FOG] and the phosphatase and tensin homolog [PTEN]) by miR-200b and miR-21 respectively, can lead to the activation of the AKT pathway, which then leads to cellular growth and migration. Indeed, higher levels of miR-200b and miR-21 levels are associated with increased fibrosis and biliary atresia respectively $[105,106]$.

Lastly, in an animal model of autosomal recessive polycystic kidney disease (ARPKD), the polycystic kidney (PCK) rat, the majority of miRNAs are downregulated, particularly miR-15a [107]. In cultured normal rat cholangiocytes, suppression of miR-15a leads to cell cycle progression and cyst growth due to increased expression of cell division cycle $25 \mathrm{~A}$ (Cdc25A) [107].

\section{Pathways of cholangiocyte biology: proliferation, apoptosis, senescence and reactivity}

\subsection{Proliferative ability}

Proliferation of cholangiocytes has been shown to be modulated by gastrointestinal hormones, bile acids, angiogenic factors, steroids, and neuropeptides and neurotransmitters, which has been well-reviewed here [108]. Importantly, by virtue of their higher nucleus to cytoplasm ratio, capacity to proliferate as well as acquire the phenotype of large cholangiocytes, it is hypothesized that small cholangiocytes are less differentiated and can act as hepatic progenitor cells $[10,74,109]$. Regardless of whether this is true, it is well known that cholangiocyte proliferation can be stimulated by a number of factors which are summarized in Table 3. The gastrointestinal hormones somatostatin and gastrin are known to inhibit cholangiocyte proliferation through the somatostatin receptor subtype 2 (SSTR2) and cholecystokinin-B (CCK-B) receptors respectively [110,111]. In a preclinical study involving PCK rats, the somatostatin analogue octreotide was shown to inhibit cholangiocyte proliferation and liver fibrosis [112]. Gastrin administration can inhibit and even reverse, through apoptotic pathways, cholangiocyte proliferation in bile duct-ligated rats [72,113]. Conversely, glucagon-like peptide 1 (GLP1) increases cholangiocyte proliferation, as does its receptor agonist exendin-4 [114]. Interestingly, exendin-4 has been shown to prevent apoptosis of cholangiocytes [115].

Bile acids may also modulate cholangiocyte proliferation, though the direction of effect is dependent on the exact bile acid in question. In vitro, taurocholate and taurolithocholic acid have been shown to stimulate the proliferation of large, but not small, cholangiocytes, as

Biochim Biophys Acta. Author manuscript; available in PMC 2018 July 01. 
well as induce secretin receptor gene expression, cAMP levels and $\mathrm{Cl}^{-} / \mathrm{HCO}_{3}{ }^{-}$exchanger activity [116]. Not only have the proliferative effects of both bile acids been replicated in rats, it has also been shown that they induce concurrent secretin-induced bicarbonate secretion in these animals [117]. By contrast, ursodeoxycholic acid (UDCA) and tauroursodeoxycholate inhibit overall cholangiocyte proliferation in BDL rats as well as reduce the expression of the cholangiocyte apical bile acid transporter, which in turn is hypothesized to reduce the ability of endogenous bile acids to stimulate proliferative and secretory pathways [118]. The inhibitory effects of UDCA likely extend to hepatic cystogenesis in polycystic liver diseases, which are characterized by biliary cysts that undergo progressive growth and secretion [119]. Chronic administration of UDCA to PCK rats inhibits cyst development and subsequent fibrosis [119]. The anti-proliferative effect of UDCA also occurs in vitro, and has been shown to be secondary to a phosphoinositide 3kinase (PI3K)/AKT/extracellular signal-regulated kinase (ERK) 1/2-dependent mechanism rather than apoptosis [119].

Angiogenic factors have been demonstrated to not only mediate the growth of vascular support structures, but also induce a concurrent proliferation of cholangiocytes. In response to bile duct ligation, cholangiocytes have an increased expression of vascular endothelial growth factor receptor (VEGFR) proteins 2 and 3, as well as increased secretion of VEGF [120]. This autocrine mechanism is mediated via the $\mathrm{IP}_{3}-\mathrm{Ca}^{2+}-\mathrm{PKCa}$ pathway [120]. Under pathologic circumstances (e.g., ADPKD), VEGF, VEGFR and additional angiogenic factors such as angiopoietin (Ang)-1 and Ang-2 and their receptor, tyrosine kinase (Tie-2) are upregulated [121]. In addition, their proliferative effect on cholangiocytes appears to be potentiated in states of disease [121].

Like angiogenic factors, serotonin appears to provide an autocrine pathway for regulation of cholangiocyte proliferation [122]. Cholangiocytes express serotonin receptors and secrete both serotonin and nerve growth factor (NGF), which have an anti-proliferative and stimulatory effect on cholangiocyte proliferation respectively $[122,123]$. Serotonin appears to act in an autocrine fashion via the $\mathrm{IP}_{3}-\mathrm{Ca}^{2+}-\mathrm{PKCa}$ pathway by downregulating cAMPdependent signals, while NGF acts in a paracrine manner through AKT- and ERK 1/2dependent pathways $[122,123]$.

Both parasympathetic and sympathetic innervation are necessary to maintain homeostatic rates of cholangiocyte proliferation [124,125]. Denervation studies involving total vagotomy (with an associated drop in cholangiocyte cAMP levels) or chemically induced adrenergic inhibition leads to reduced cholangiocyte proliferation, increased apoptosis and reduces secretin-induced choleresis [124,125]. Furthermore, knockout of alpha-calcitonin gene related peptide (a-CGRP), a neuropeptide involved in the innervation of sensory nerves, leads to a decrease in proliferation following bile duct-ligation, which is rescued by the administration of a-CGRP [126].

Cholangiocytes constitutively express all histamine receptor subtypes, but the histamine H3 receptor (HH3R) has been shown to be particularly upregulated in bile duct-ligated rats [127]. This is associated with diminished proliferation in the absence of increased apoptosis [127]. 
As certain cholangiopathies, such as $\mathrm{PBC}$, predominantly affect a particular sex, there has been an interest in evaluating the role of sex hormones in bile duct proliferation. Cholangiocytes express both estrogen receptor-alpha and -beta (ER- $\alpha$ and ER- $\beta$ ), and undergo an upregulation of ER- $\beta$ following bile duct-ligation [128]. In turn, addition of 17$\beta$-estradiol has been shown to induce proliferation through the Src-Shc-ERK1/2 pathway [129]. Inhibition of estrogen signaling in both female and male rats through ovariectomy and tamoxifen respectively leads to decreased cholangiocyte proliferation and an increase in apoptosis $[128,130]$.

Another hormone that increases cholangiocyte proliferation is gonadotropin-releasing hormone $(\mathrm{GnRH})$ [131]. Both normal cholangiocytes, as well as cholangiocytes under cholestatic conditions (e.g., BDL rats) express GnRH receptors [131]. In both in vivo and in vitro experiments, treatment with GnRH causes biliary proliferation through an autocrine pathway, whereas knockdown or pharmacologic inhibition of GnRH abrogates this effect [131].

Lastly, matrix metalloproteinases (MMPs) may play a role in biliary proliferation, particularly in the setting of polycystic liver diseases [132]. These proteases are responsible for remodeling the extracellular matrix and are upregulated in cholangiocytes from humans with polycystic liver disease and PCK rats [132]. The proliferative ability of MMPs is mediated by interleukin (IL)- 6 and IL-8, and can be inhibited by pharmacologic means, leading to suppression of cyst formation and subsequent fibrogenesis [132].

\subsection{Apoptotic pathways}

It is known that cholangiocytes apoptose under both normal and pathologic conditions. During ductal development, for example, apoptosis is a normal phenomenon that allows for the regression of the ductal plate [133]. Apoptosis is also the mechanism by which aberrant ductal proliferation is reversed in the setting of transient biliary obstruction [134]. Apoptosis has also been implicated in cholestatic liver diseases such as PBC, PSC and biliary atresia $[135,136]$. Circulating markers of apoptosis have been found in patients with PBC and PSC [135]. Furthermore, human cholangiocytes from patients with PSC or PBC express higher levels of TNF-related apoptosis-inducing ligand (TRAIL) and demonstrate greater apoptosis [137]. Apoptosis has also been demonstrated in rodent models of cholestatic liver disease [137-139].

\subsection{Senescent ability}

In response to cellular injury, cells that fail to undergo repair may potentially follow a pathway to either apoptosis or to cellular senescence (cell cycle arrest); it has been demonstrated that senescent cholangiocytes accumulate in a number of chronic liver diseases, especially PSC, which may be one of the mechanisms that leads to fibrosis $[140,141]$. Senescent cholangiocytes are irreversibly arrested at the $\mathrm{G}_{1}$ phase of the cell cycle and do not respond to various external stimuli even though they remain metabolically active [142]. Once cellular senescence is established, cells become resistant to apoptosis and thus the senescent phenotype may be the mechanism by which cells inhibit propagation or neoplastic transformation of damaged cells [143].

Biochim Biophys Acta. Author manuscript; available in PMC 2018 July 01. 
Two major tumor suppressor pathways control cellular senescence. These involve activation of the cyclin-dependent kinase inhibitors $(\mathrm{CDKN}) \mathrm{p} 21^{\mathrm{CIP} 1}$ and $\mathrm{P} 16^{\mathrm{INK} 4 \mathrm{~A}}$, which are mediated by the $\mathrm{p} 53$ and the retinoblastoma (pRB) proteins respectively [143]. In in vitro and in vivo experiments, overexpression of constitutively active neuroblastoma RAS viral oncogene homolog (NRAS) has been shown to promote cyclin-dependent kinase inhibitor $2 \mathrm{~A}(\mathrm{CDKN} 2 \mathrm{~A}) / \mathrm{p} 16^{\mathrm{INK} 4 \mathrm{a}}$ expression and cholangiocyte senescence in an ETS protooncogene 1 (ETS1)-dependent manner [144]. NRAS/MAPK promotes ETS1/2-dependent transcription of p16 and insult-induced senescence [144].

This relationship has been recently demonstrated in cholangiocytes of patients with PSC. Cholangiocytes of PSC patients appear to be largely senescent, with active NRAS [144]. The addition of a microbial insult (modelled by LPS) activates a NRAS-dependent pathway that involves $\mathrm{CDKN} 2 \mathrm{~A} / \mathrm{p} 16^{\mathrm{INK} 4 \mathrm{a}}$ and leads to senescence in normal human cholangiocytes [144]. The CDKN2A/p16 ${ }^{\text {INK4a }}$ pathway is driven by ETS1, which can bind to the $\mathrm{CDKN} 2 \mathrm{~A} / \mathrm{p} 16^{\mathrm{INK} 4 \mathrm{a}}$ promoter, demonstrating that it is a direct transcriptional regulator [144]. Increased expression of phosphorylated ETS1 was also demonstrated in human PSC liver samples as well as a murine model of PSC. In addition, it was shown that CDKN2A repression is controlled by a repressive histone 3 lysine 4 trimethylaton (H3K4Me3) mark, which is converted to a permissive mark after exposure with long-term LPS treatment. This then allows ETS1 to bind to CDKN2A, demonstrating that there is epigenetic regulation involved the binding of ETS1.

Another mechanism which may be implicated in the regulation of cholangiocyte senescence includes the forkhead box A2 (FoxA2) [145]. FoxA2 regulates cell differentiation and tissue regeneration, and has been found to be constitutively upregulated in murine liver progenitor cells and small mouse cholangiocytes as compared to large mouse cholangiocytes [145]. Furthermore, FoxA2 was silenced in liver tissues derived from patients with cholestatic liver disease (PSC and PBC). After BDL and MDR2 ${ }^{-1-}$ mice (a murine model of PSC) were treated with stem cell therapy involving small mouse cholangiocytes, pathways indicative of fibrosis and hepatic senescence were diminished, while those involving HSC senescence were increased [145]. This suggests that FoxA2 is integral in regulating both fibrosis and divergent senescent pathways [145].

Senescent cells can also transition to a potentially pathologic state which involves hypersecretion of proinflammatory cytokines such as IL-6 and chemokines such as IL-8 [146]. This state is referred to as a senescence-associated secretory phenotype (SASP) [147]. SASP affects neighboring cells and the microenvironment by inducing and reinforcing senescence, activating immune responses, inducing fibrosis and even potentiating tumorigenesis [148]. Escape of cholangiocytes from the senescent state is considered a key mechanism in the development of cholangiocarcinoma, the neoplastic transformation of cholangiocytes [149].

Despite the striking heterogeneity between small and large cholangiocytes, it is less clear whether they have differential responses with regards to senescence and eventual fibrosis. The engraftment of transplanted small mouse cholangiocytes in BDL mice results in increased FoxA2 and decreased fibrosis, demonstrating that small cholangiocytes can induce 
recovery to cholestatic injury [145]. And yet, as discussed above, evidence suggests that both small and large cholangiocytes can exhibit senescence in pathologic settings, such as PSC, which classically affects the large bile ducts, and PBC, which affects the small bile ducts [145]. Senescent cholangiocytes have also been discovered in diseases that arise from hepatocellular injury, such as non-alcoholic steatohepatitis and viral hepatitis [141]. Thus, it is possible that in states of disease, the reparative ability of small cholangiocytes is overwhelmed by the presence of senescent, abnormally functioning small cholangiocytes, thereby leading to progressive injury and fibrosis [145].

\section{The reactive cholangiocyte}

All cholangiopathies react to injury by manifesting varying degrees of ductopenia, bile duct hyperplasia, inflammation, fibrosis and cholestasis [150,151]. Ductopenia occurs as a consequence of disproportionate destruction and proliferation of cholangiocytes [152]. The exact mechanism and pathways by which cholangiocyte death occurs is unknown, but it is postulated to occur either through lysis and/or apoptosis, with apoptosis thought to be the dominant mechanism [153]. After an insult, proliferation is activated in particular cholangiocyte subpopulations in order to compensate for the loss of biliary cells and to sustain adequate secretory and absorptive functions $[1,74]$. These "reactive cholangiocytes" are characterized by an enhanced proinflammatory response, including the secretion of several proinflammatory (e.g., TNF-a, IL-6, and IL-8) and chemotactic cytokines (e.g., monocyte chemotactic protein-1, cytokine-induced neutrophil chemoattractant) and growth factors that enable them to recruit inflammatory and mesenchymal cells that promote biliary remodeling (Fig. 3) [154-157]. These features are a component of an intricate crosstalk between a variety of resident and recruited mesenchymal cells (HSC, portal fibroblasts, myofibroblasts, and fibrocytes), endothelial cells, macrophages, and lymphocytes [158]. Angiogenesis is also stimulated by secretion of VEGF, endothelin-1, platelet-derived growth factor-BB, transforming growth factor- $\beta 2$ (TGF- $\beta 2$ ), and connective tissue growth factor [159]. Reactive cholangiocytes also have decreased expression of epithelial markers and acquire mesenchymal features, which play an important role in modulation of the reparative response. The consequence of all these events is the development of portal fibrosis in cholangiopathies [160].

One of the pathways that mediates repair following injury to cholangiocytes is the $\mathrm{Hh}$ signaling pathway [161]. Hh ligands stimulate cholangiocytes to express chemokines that recruit mononuclear cell types with cognate receptors for these chemokines, thereby orchestrating a repair-related mechanism for liver inflammation [162]. In addition, activation of the Hh signaling pathway stimulates the accumulation of ductular-type progenitor cells and myofibroblasts [163]. In BDL models of biliary injury, Hh ligand expression and activity is upregulated; these changes are reversed when the biliary obstruction is relieved [163].

In settings of acute or chronic liver injury, however, cholangiocytes can also actively begin secreting paracrine factors that are hypothesized to permit communication with local cells such as HSC, fibroblasts and inflammatory cells. These include IL-6, IL-8, TNF-a, plateletderived growth factor, endothelin-1, TGF- $\beta$, nitric oxide and monocyte chemotactic 
protein-1 [164-170]. Thus, it is likely that cholangiocytes not only have reparative properties, but may also potentiate local injury.

Gut-derived bacterial products, such as LPS, activate the inflammatory cascade in immune cells, modulate the function of liver parenchymal cells, and contribute to chronic liver diseases [171,172]. Recently, it was showed that the expression of NLR pyrin domaincontaining protein 3 (Nlrp3) inflammasome is increased in reactive cholangiocytes of both in vitro and in vivo models of a PSC, leading to the secretion of IL-18 and alteration of the epithelial barrier function of cholangiocytes with significantly decreased the expression of zonulin-1 and e-cadherin [173].

In culture, it has been demonstrated that LPS induces activation of NRAS through Toll-like receptor 4 via NF- $\kappa B$ in human cholangiocytes [140]. Growth factor receptor-bound protein (Grb2), a downstream mediator of epidermal growth factor receptor (EGFR), is essential for this activation. Stimulation of the NRAS/MAPK pathway and NF-kB activation promotes a robust proinflammatory response with IL-6 expression and the consequent activation of cholangiocyte proliferation [174].

\section{Conclusion}

In summary, cholangiocytes are heterogeneous epithelial cells capable of highly specialized functions. Small and large cholangiocytes possess unique cellular ultrastructure and polarized membrane proteins that allow different responses to homeostatic stimuli as well as to injury. Far from being passive structures, however, cholangiocytes can sense and respond to endogenous molecules (bile acids, oxysterols, nucleotides) as well as exogenous, microbial-derived metabolites including LPS present in bile. In response, cholangiocytes can release autocrine and paracrine signals to maintain homeostasis or to adapt a proinflammatory phenotype. Additionally, cholangiocytes have been shown to be capable of undergoing senescence, which provides protection against neoplastic development, but can also contribute to disease due to the development of an aberrant phenotype such as SASP. Understanding the pathophysiology underpinning differentiation into a proliferative, reactive, senescent or inflammatory phenotype, may lead to the development of novel therapeutics and enhance biomarker discovery.

\section{Acknowledgments}

This work was supported by the NIH/NIDDK DK57993, the NIH/NIDDK DK24301 (R01), the Mayo Center for Cell Signaling in Gastroenterology grant DK84567 (P30), the Chris M. Carlos and Catharine N. Jockisch Carlos Foundation for PSC.

\section{Abbreviations}

a-CGRP alpha-calcitonin gene related peptide

Ang angiopoietin

AE2 anion exchanger 2

ADP adenosine diphosphate 


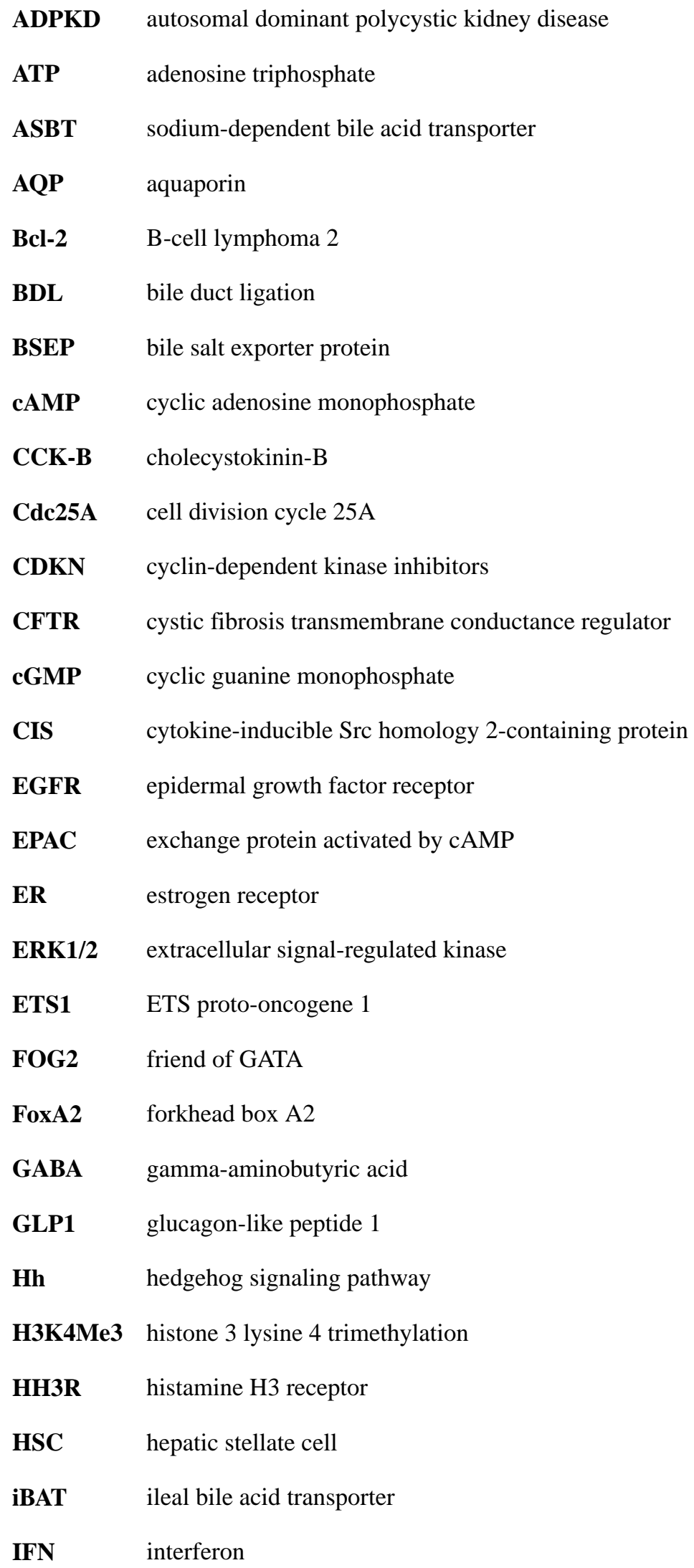




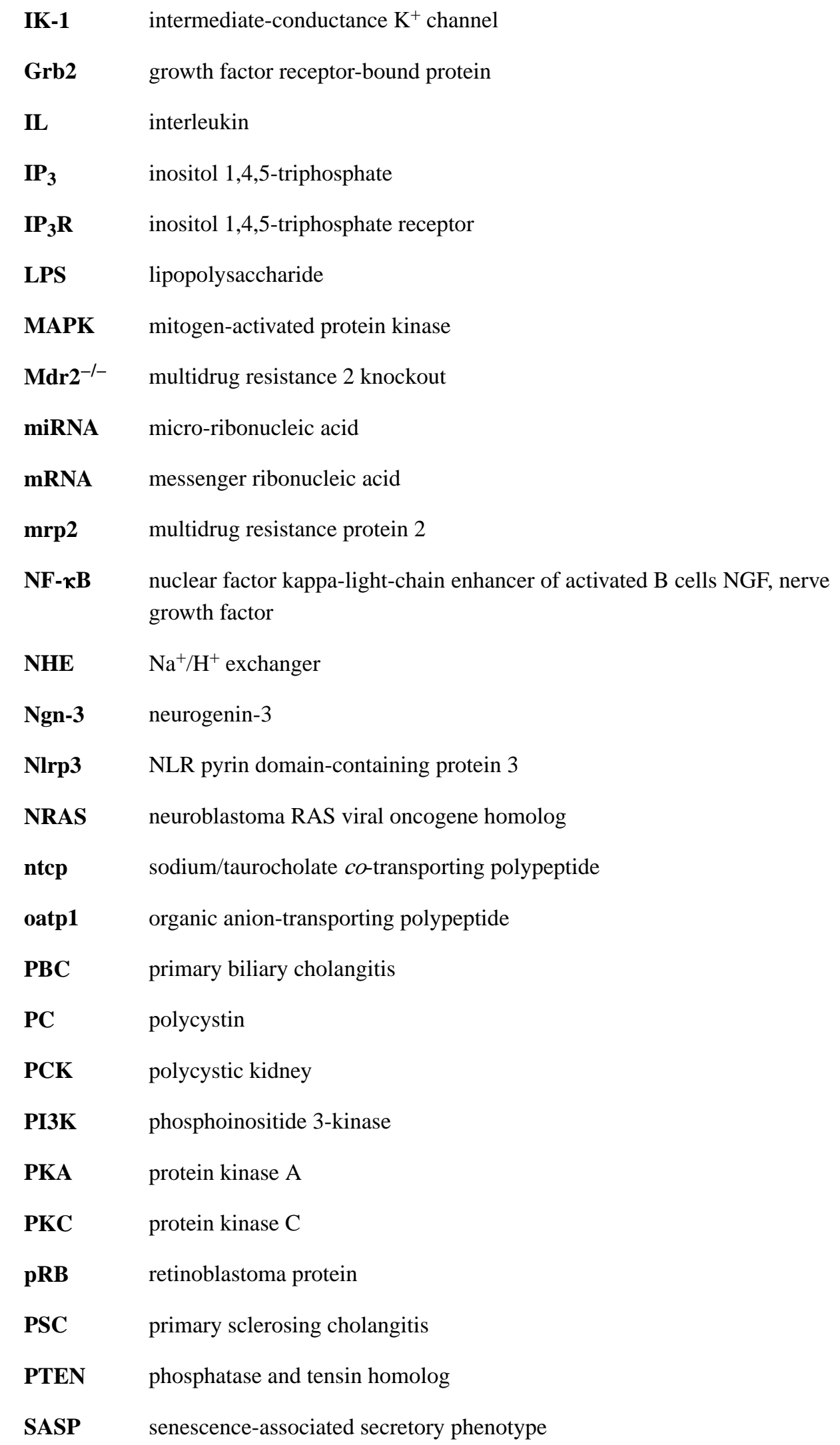


SK2 small conductance $\mathrm{K}^{+}$channel

SGLT1 sodium-dependent glucose cotransporters

Smad small mothers against decapentaplegic

SSTR2 somatostatin receptor subtype 2

TGF transforming growth factor

TNF tumor necrosis factor

TRAIL (TNF)-related apoptosis-inducing ligand

TRPV4 transient receptor potential vaniloid 4

VEGR vascular endothelial growth factor

VEGFR vascular endothelial growth factor receptor

VIP vasoactive polypeptide

\section{References}

1. O'Hara SP, Tabibian JH, Splinter PL, et al. The dynamic biliary epithelia: molecules, pathways, and disease. J. Hepatol. 2013; 58:575-582. [PubMed: 23085249]

2. Carpenter HA. Bacterial and parasitic cholangitis. Mayo Clin. Proc. 1998; 73:473-478. [PubMed: 9581592]

3. Alpini, G., Prall, RT., LaRusso, NF. The pathobiology of biliary epithelia. In: Arias, IM., editor. The Liver: Biology and Pathology. 4. Lippincott Williams \& Wilkins; Philadelphia: 2001.

4. Ludwig J, Ritman EL, LaRusso NF, et al. Anatomy of the human biliary system studied by quantitative computer-aided three-dimensional imaging techniques. Hepatology. 1998; 27:893-899. [PubMed: 9537426]

5. Strazzabosco M, Fabris L. Functional anatomy of normal bile ducts. Anat. Rec. (Hoboken). 2008; 291:653-660. [PubMed: 18484611]

6. Ludwig J. New concepts in biliary cirrhosis. Semin. Liver Dis. 1987; 7:293-301. [PubMed: 3324348]

7. Steiner JW, Carruthers JS. Studies on the fine structure of the terminal branches of the biliary tree: I. The morphology of normal bile canaliculi, bile pre-ductules (ducts of Hering) and bile ductules. Am. J. Pathol. 1961; 38:639-661. [PubMed: 19971000]

8. Schaffner F, Popper H. Electron microscopic studies of normal and proliferated bile ductules. Am. J. Pathol. 1961; 38:393-410. [PubMed: 13747220]

9. Alpini G, Roberts S, Kuntz SM, et al. Morphological, molecular, and functional heterogeneity of cholangiocytes from normal rat liver. Gastroenterology. 1996; 110:1636-1643. [PubMed: 8613073]

10. Benedetti A, Bassotti C, Rapino K, et al. A morphometric study of the epithelium lining the rat intrahepatic biliary tree. Hepatol. J. 1996; 24:335-342.

11. Glaser S, Francis H, Demorrow S, et al. Heterogeneity of the intrahepatic biliary epithelium. World J. Gastroenterol. 2006; 12:3523-3536. [PubMed: 16773709]

12. Marzioni M, Glaser SS, Francis H, et al. Functional heterogeneity of cholangiocytes. Semin. Liver Dis. 2002; 22:227-240. [PubMed: 12360417]

13. Vestentoft PS, Jelnes P, Hopkinson BM, et al. Three-dimensional reconstructions of intrahepatic bile duct tubulogenesis in human liver. BMC Dev. Biol. 2011; 11:56. [PubMed: 21943389]

14. Tremblay KD, Zaret KS. Distinct populations of endoderm cells converge to generate the embryonic liver bud and ventral foregut tissues. Dev. Biol. 2005; 280:87-99. [PubMed: 15766750] 
15. Crawford JM. Development of the intrahepatic biliary tree. Semin. Liver Dis. 2002; 22:213-226. [PubMed: 12360416]

16. Gaudio E, Franchitto A, Pannarale L, et al. Cholangiocytes and blood supply. World J. Gastroenterol. 2006; 12:3546-3552. [PubMed: 16773711]

17. Terada T, Nakanuma Y. Innervation of intrahepatic bile ducts and peribiliary glands in normal human livers, extrahepatic biliary obstruction and hepatolithiasis. An immunohistochemical study. J. Hepatol. 1989; 9:141-148. [PubMed: 2809154]

18. Akiyoshi H, Gonda T, Terada T. A comparative histochemical and immunohistochemical study of aminergic, cholinergic and peptidergic innervation in rat, hamster, guinea pig, dog and human livers. Liver. 1998; 18:352-359. [PubMed: 9831365]

19. Burt AD, Tiniakos D, MacSween RN, et al. Localization of adrenergic and neuropeptide tyrosinecontaining nerves in the mammalian liver. Hepatology. 1989; 9:839-845. [PubMed: 2565863]

20. el-Salhy M, Stenling R, Grimelius L. Peptidergic innervation and endocrine cells in the human liver. Scand. J. Gastroenterol. 1993; 28:809-815. [PubMed: 7694356]

21. Ritchie HD, Grindlay JH, Bollman JL. Flow of lymph from the canine liver. Am. J. Phys. 1959; 196:105-109.

22. Vroman B, LaRusso NF. Development and characterization of polarized primary cultures of rat intrahepatic bile duct epithelial cells. Lab. Investig. 1996; 74:303-313. [PubMed: 8569194]

23. Masyuk AI, Masyuk TV, LaRusso NF. Cholangiocyte primary cilia in liver health and disease. Dev. Dyn. 2008; 237:2007-2012. [PubMed: 18407555]

24. Doctor RB, Dahl R, Fouassier L, et al. Cholangiocytes exhibit dynamic, actin-dependent apical membrane turnover. Am. J. Physiol. Cell Physiol. 2002; 282:C1042-52. [PubMed: 11940520]

25. Doctor RB, Fouassier L. Emerging roles of the actin cytoskeleton in cholangiocyte function and disease. Semin. Liver Dis. 2002; 22:263-276. [PubMed: 12360420]

26. Ishii M, Vroman B, LaRusso NF. Morphologic demonstration of receptor-mediated endocytosis of epidermal growth factor by isolated bile duct epithelial cells. Gastroenterology. 1990; 98:12841291. [PubMed: 1691119]

27. Hurley JH, Odorizzi G. Get on the exosome bus with ALIX. Nat. Cell Biol. 2012; 14:654-655. [PubMed: 22743708]

28. Bang C, Thum T. Exosomes: new players in cell-cell communication. Int. J. Biochem. Cell Biol. 2012; 44:2060-2064. [PubMed: 22903023]

29. Bode HP, Wang L, Cassio D, et al. Expression and regulation of gap junctions in rat cholangiocytes. Hepatology. 2002; 36:631-640. [PubMed: 12198655]

30. Okada Y, Jinno K, Moriwaki S, et al. Blood group antigens in the intrahepatic biliary tree. I. Distribution in the normal liver. J. Hepatol. 1988; 6:63-70. [PubMed: 3279107]

31. Lakehal F, Wendum D, Barbu V, et al. Phase I and phase II drug-metabolizing enzymes are expressed and heterogeneously distributed in the biliary epithelium. Hepatology. 1999; 30:1498_ 1506. [PubMed: 10573530]

32. Terada T, Kono N, Nakanuma Y. Immunohistochemical and immunoelectron microscopic analyses of alpha-amylase isozymes in human intrahepatic biliary epithelium and hepatocytes. J. Histochem. Cytochem. 1992; 40:1627-1635. [PubMed: 1431051]

33. Charlotte F, L'Hermine A, Martin N, et al. Immunohistochemical detection of bcl-2 protein in normal and pathological human liver. Am. J. Pathol. 1994; 144:460-465. [PubMed: 8129031]

34. Martinez-Anso E, Castillo JE, Diez J, et al. Immunohistochemical detection of chloride/ bicarbonate anion exchangers in human liver. Hepatology. 1994; 19:1400-1406. [PubMed: 8188169]

35. Alpini G, Lenzi R, Zhai WR, et al. Bile secretory function of intrahepatic biliary epithelium in the rat. Am. J. Phys. 1989; 257:G124-33.

36. Boyer JL, Bloomer JR. Canalicular bile secretion in man. Studies utilizing the biliary clearance of (14C)mannitol. J. Clin. Invest. 1974; 54:773-781. [PubMed: 4610005]

37. Glaser S, Wang M, Ueno Y, et al. Differential transcriptional characteristics of small and large biliary epithelial cells derived from small and large bile ducts. Am. J. Physiol. Gastrointest. Liver Physiol. 2010; 299:G769-77. [PubMed: 20576918] 
38. Ueno Y, Alpini G, Yahagi K, et al. Evaluation of differential gene expression by microarray analysis in small and large cholangiocytes isolated from normal mice. Liver Int. 2003; 23:449 459. [PubMed: 14986819]

39. Kanno N, LeSage G, Glaser S, et al. Regulation of cholangiocyte bicarbonate secretion. Am. J. Physiol. Gastrointest. Liver Physiol. 2001; 281:G612-25. [PubMed: 11518673]

40. Hirata K, Nathanson MH. Bile duct epithelia regulate biliary bicarbonate excretion in normal rat liver. Gastroenterology. 2001; 121:396-406. [PubMed: 11487549]

41. Minagawa N, Nagata J, Shibao K, et al. Cyclic AMP regulates bicarbonate secretion in cholangiocytes through release of ATP into bile. Gastroenterology. 2007; 133:1592-1602. [PubMed: 17916355]

42. Dutta AK, Woo K, Doctor RB, et al. Extracellular nucleotides stimulate Cl-currents in biliary epithelia through receptor-mediated IP3 and $\mathrm{Ca}^{2+}$ release. Am. J. Physiol. Gastrointest. Liver Physiol. 2008; 295:G1004-15. [PubMed: 18787062]

43. Woo K, Dutta AK, Patel V, et al. Fluid flow induces mechanosensitive ATP release, calcium signalling and $\mathrm{Cl}$-transport in biliary epithelial cells through a PKCzeta-dependent pathway. J. Physiol. 2008; 586:2779-2798. [PubMed: 18388137]

44. Dutta AK, Khimji AK, Sathe M, et al. Identification and functional characterization of the intermediate-conductance $\mathrm{Ca}(2+)$-activated $\mathrm{K}(+)$ channel (IK-1) in biliary epithelium. Am. J. Physiol. Gastrointest. Liver Physiol. 2009; 297:G1009-18. [PubMed: 20501432]

45. Uriarte I, Banales JM, Saez E, et al. Bicarbonate secretion of mouse cholangiocytes involves $\mathrm{Na}(+)-\mathrm{HCO}(3)(-)$ cotransport in addition to $\mathrm{Na}(+)$-independent $\mathrm{Cl}(-) / \mathrm{HCO}(3)(-)$ exchange. Hepatology. 2010; 51:891-902. [PubMed: 20041402]

46. Spirli C, Granato A, Zsembery K, et al. Functional polarity of $\mathrm{Na}+/ \mathrm{H}+$ and $\mathrm{Cl}-/ \mathrm{HCO} 3$-exchangers in a rat cholangiocyte cell line. Am. J. Phys. 1998; 275:G1236-45.

47. Mennone A, Biemesderfer D, Negoianu D, et al. Role of sodium/hydrogen exchanger isoform NHE3 in fluid secretion and absorption in mouse and rat cholangiocytes. Am. J. Physiol. Gastrointest. Liver Physiol. 2001; 280:G247-54. [PubMed: 11208547]

48. Lazaridis KN, Pham L, Vroman B, et al. Kinetic and molecular identification of sodium-dependent glucose transporter in normal rat cholangiocytes. Am. J. Phys. 1997; 272:G1168-74.

49. Ballatori N, Jacob R, Barrett C, et al. Biliary catabolism of glutathione and differential reabsorption of its amino acid constituents. Am. J. Phys. 1988; 254:G1-7.

50. Lazaridis KN, Pham L, Tietz P, et al. Rat cholangiocytes absorb bile acids at their apical domain via the ileal sodium-dependent bile acid transporter. J. Clin. Invest. 1997; 100:2714-2721. [PubMed: 9389734]

51. Masyuk AI, LaRusso NF. Aquaporins in the hepatobiliary system. Hepatology. 2006; 43:S75-81. [PubMed: 16447276]

52. Strazzabosco M, Joplin R, Zsembery A, et al. $\mathrm{Na}(+)$-dependent and -independent $\mathrm{Cl}-/ \mathrm{HCO}-3$ exchange mediate cellular $\mathrm{HCO}_{3}$-transport in cultured human intrahepatic bile duct cells. Hepatology. 1997; 25:976-985. [PubMed: 9096607]

53. Maylie J, Bond CT, Herson PS, et al. Small conductance $\mathrm{Ca}^{2+}$-activated $\mathrm{K}+$ channels and calmodulin. J. Physiol. 2004; 554:255-261. [PubMed: 14500775]

54. Feranchak AP, Doctor RB, Troetsch M, et al. Calcium-dependent regulation of secretion in biliary epithelial cells: the role of apamin-sensitive SK channels. Gastroenterology. 2004; 127:903-913. [PubMed: 15362045]

55. Feranchak AP, Fitz JG. Adenosine triphosphate release and purinergic regulation of cholangiocyte transport. Semin. Liver Dis. 2002; 22:251-262. [PubMed: 12360419]

56. Tietz PS, Holman RT, Miller LJ, et al. Isolation and characterization of rat cholangiocyte vesicles enriched in apical or basolateral plasma membrane domains. Biochemistry. 1995; 34:1543615443. [PubMed: 7492544]

57. Tabibian JH, Masyuk AI, Masyuk TV, et al. Physiology of cholangiocytes. Compr. Physiol. 2013; 3:541-565. [PubMed: 23720296]

58. Benedetti A, Di Sario A, Marucci L, et al. Carrier-mediated transport of conjugated bile acids across the basolateral membrane of biliary epithelial cells. Am. J. Phys. 1997; 272:G1416-24.

59. Boyer JL. Bile formation and secretion. Compr. Physiol. 2013; 3:1035-1078. [PubMed: 23897680] 
60. Hammond CL, Lee TK, Ballatori N. Novel roles for glutathione in gene expression, cell death, and membrane transport of organic solutes. J. Hepatol. 2001; 34:946-954. [PubMed: 11451183]

61. Boyer, JL. Bile Formation and Cholestasis. Lippincott Williams \& Williams; Philadelphia, PA: 2003.

62. Masyuk, AI., Masyuk, TV., LaRusso, F. Physiology of Cholangiocytes. Academic Press; New York: 2006.

63. Alpini G, Glaser S, Robertson W, et al. Large but not small intrahepatic bile ducts are involved in secretin-regulated ductal bile secretion. Am. J. Phys. 1997; 272:G1064-74.

64. Chignard N, Mergey M, Barbu V, et al. VPAC1 expression is regulated by FXR agonists in the human gallbladder epithelium. Hepatology. 2005; 42:549-557. [PubMed: 16037943]

65. Cho WK, Boyer JL. Characterization of ion transport mechanisms involved in bombesin-stimulated biliary secretion in rat cholangiocytes. J. Hepatol. 1999; 30:1045-1051. [PubMed: 10406182]

66. Alvaro D, Gigliozzi A, Marucci L, et al. Corticosteroids modulate the secretory processes of the rat intrahepatic biliary epithelium. Gastroenterology. 2002; 122:1058-1069. [PubMed: 11910357]

67. Masyuk AI, Gradilone SA, Banales JM, et al. Cholangiocyte primary cilia are chemosensory organelles that detect biliary nucleotides via P2Y12 purinergic receptors. Am. J. Physiol. Gastrointest. Liver Physiol. 2008; 295:G725-34. [PubMed: 18687752]

68. Alvaro D, Alpini G, Jezequel AM, et al. Role and mechanisms of action of acetylcholine in the regulation of rat cholangiocyte secretory functions. J. Clin. Invest. 1997; 100:1349-1362. [PubMed: 9294100]

69. LeSage GD, Alvaro D, Glaser S, et al. Alpha-1 adrenergic receptor agonists modulate ductal secretion of BDL rats via $\mathrm{Ca}(2+)$ - and PKC-dependent stimulation of cAMP. Hepatology. 2004; 40:1116-1127. [PubMed: 15486932]

70. Gong AY, Tietz PS, Muff MA, et al. Somatostatin stimulates ductal bile absorption and inhibits ductal bile secretion in mice via SSTR2 on cholangiocytes. Am. J. Physiol. Cell Physiol. 2003; 284:C1205-14. [PubMed: 12676656]

71. Rene E, Danzinger RG, Hofmann AF, et al. Pharmacologic effect of somatostatin on bile formation in the dog. Enhanced ductular reabsorption as the major mechanism of anticholeresis.

Gastroenterology. 1983; 84:120-129. [PubMed: 6128285]

72. Glaser S, Alvaro D, Ueno Y, et al. Gastrin reverses established cholangiocyte proliferation and enhanced secretin-stimulated ductal secretion of BDL rats by activation of apoptosis through increased expression of Ca2+-dependent PKC isoforms. Liver Int. 2003; 23:78-88. [PubMed: 12698962]

73. Glaser S, Alvaro D, Roskams T, et al. Dopaminergic inhibition of secretin-stimulated choleresis by increased PKC-gamma expression and decrease of PKA activity. Am. J. Physiol. Gastrointest. Liver Physiol. 2003; 284:G683-94. [PubMed: 12505882]

74. Mancinelli R, Franchitto A, Gaudio E, et al. After damage of large bile ducts by gammaaminobutyric acid, small ducts replenish the biliary tree by amplification of calcium-dependent signaling and de novo acquisition of large cholangiocyte phenotypes. Am. J. Pathol. 2010; 176:1790-1800. [PubMed: 20185575]

75. Masyuk AI, Masyuk TV, Splinter PL, et al. Cholangiocyte cilia detect changes in luminal fluid flow and transmit them into intracellular $\mathrm{Ca} 2+$ and cAMP signaling. Gastroenterology. 2006; 131:911-920. [PubMed: 16952559]

76. Gradilone SA, Masyuk AI, Splinter PL, et al. Cholangiocyte cilia express TRPV4 and detect changes in luminal tonicity inducing bicarbonate secretion. Proc. Natl. Acad. Sci. U. S. A. 2007; 104:19138-19143. [PubMed: 18024594]

77. Handel M, Schulz S, Stanarius A, et al. Selective targeting of somatostatin receptor 3 to neuronal cilia. Neuroscience. 1999; 89:909-926. [PubMed: 10199624]

78. Brailov I, Bancila M, Brisorgueil MJ, et al. Localization of 5-HT(6) receptors at the plasma membrane of neuronal cilia in the rat brain. Brain Res. 2000; 872:271-275. [PubMed: 10924708]

79. Whitfield JF. The neuronal primary cilium-an extrasynaptic signaling device. Cell. Signal. 2004; 16:763-767. [PubMed: 15115655] 
80. Masyuk AI, Huang BQ, Radtke BN, et al. Ciliary subcellular localization of TGR5 determines the cholangiocyte functional response to bile acid signaling. Am. J. Physiol. Gastrointest. Liver Physiol. 2013; 304:G1013-24. [PubMed: 23578785]

81. Keitel V, Haussinger D. Perspective: TGR5 (Gpbar-1) in liver physiology and disease. Clin. Res. Hepatol. Gastroenterol. 2012; 36:412-419. [PubMed: 22521118]

82. Mori S, Chang JT, Andrechek ER, et al. Anchorage-independent cell growth signature identifies tumors with metastatic potential. Oncogene. 2009; 28:2796-2805. [PubMed: 19483725]

83. Gradilone SA, Radtke BN, Bogert PS, et al. HDAC6 inhibition restores ciliary expression and decreases tumor growth. Cancer Res. 2013; 73:2259-2270. [PubMed: 23370327]

84. Ameres SL, Zamore PD. Diversifying microRNA sequence and function. Nat. Rev. Mol. Cell Biol. 2013; 14:475-488. [PubMed: 23800994]

85. O'Hara SP, Gradilone SA, Masyuk TV, et al. MicroRNAs in cholangiopathies. Curr. Pathobiol. Rep. 2014; 2:133-142. [PubMed: 25097819]

86. Allen RM, Marquart TJ, Albert CJ, et al. miR-33 controls the expression of biliary transporters, and mediates statin- and diet-induced hepatotoxicity. EMBO Mol. Med. 2012; 4:882-895. [PubMed: 22767443]

87. Li T, Francl JM, Boehme S, et al. Regulation of cholesterol and bile acid homeostasis by the cholesterol 7alpha-hydroxylase/steroid response element-binding protein 2/microRNA-33a axis in mice. Hepatology. 2013; 58:1111-1121. [PubMed: 23536474]

88. Chiang JY. Bile acid regulation of gene expression: roles of nuclear hormone receptors. Endocr. Rev. 2002; 23:443-463. [PubMed: 12202460]

89. Morotti RA, Suchy FJ, Magid MS. Progressive familial intrahepatic cholestasis (PFIC) type 1, 2 , and 3: a review of the liver pathology findings. Semin. Liver Dis. 2011; 31:3-10. [PubMed: 21344347]

90. de Aguiar Vallim TQ, Tarling EJ, Kim T, et al. MicroRNA-144 regulates hepatic ATP binding cassette transporter A1 and plasma high-density lipoprotein after activation of the nuclear receptor farnesoid X receptor. Circ. Res. 2013; 112:1602-1612. [PubMed: 23519696]

91. Ramirez CM, Rotllan N, Vlassov AV, et al. Control of cholesterol metabolism and plasma highdensity lipoprotein levels by microRNA-144. Circ. Res. 2013; 112:1592-1601. [PubMed: 23519695]

92. Chang J, Nicolas E, Marks D, et al. miR-122, a mammalian liver-specific microRNA, is processed from hor mRNA and may downregulate the high affinity cationic amino acid transporter CAT-1. RNA Biol. 2004; 1:106-113. [PubMed: 17179747]

93. Song KH, Li T, Owsley E, et al. A putative role of micro RNA in regulation of cholesterol 7alphahydroxylase expression in human hepatocytes. J. Lipid Res. 2010; 51:2223-2233. [PubMed: 20351063]

94. Gong AY, Zhou R, Hu G, et al. MicroRNA-513 regulates B7-H1 translation and is involved in IFNgamma-induced B7-H1 expression in cholangiocytes. J. Immunol. 2009; 182:1325-1333. [PubMed: 19155478]

95. Liaskou E, Jeffery LE, Trivedi PJ, et al. Loss of CD28 expression by liver-infiltrating T cells contributes to pathogenesis of primary sclerosing cholangitis. Gastroenterology. 2014; 147:221232. e7. [PubMed: 24726754]

96. Mao TK, Lian ZX, Selmi C, et al. Altered monocyte responses to defined TLR ligands in patients with primary biliary cirrhosis. Hepatology. 2005; 42:802-808. [PubMed: 16175622]

97. Feldman AG, Mack CL. Biliary atresia: cellular dynamics and immune dysregulation. Semin. Pediatr. Surg. 2012; 21:192-200. [PubMed: 22800972]

98. Hu G, Zhou R, Liu J, et al. MicroRNA-98 and let-7 confer cholangiocyte expression of cytokineinducible Src homology 2-containing protein in response to microbial challenge. J. Immunol. 2009; 183:1617-1624. [PubMed: 19592657]

99. Kennedy LL, Meng F, Venter JK, et al. Knockout of microRNA-21 reduces biliary hyperplasia and liver fibrosis in cholestatic bile duct ligated mice. Lab. Investig. 2016; 96:1256-1267. [PubMed: 27775690] 
100. Lin L, Gan H, Zhang H, et al. MicroRNA21 inhibits SMAD7 expression through a target sequence in the $3^{\prime}$ untranslated region and inhibits proliferation of renal tubular epithelial cells. Mol. Med. Rep. 2014; 10:707-712. [PubMed: 24913635]

101. Banales JM, Saez E, Uriz M, et al. Up-regulation of microRNA 506 leads to decreased Cl-/ $\mathrm{HCO} 3$-anion exchanger 2 expression in biliary epithelium of patients with primary biliary cirrhosis. Hepatology. 2012; 56:687-697. [PubMed: 22383162]

102. Hall C, Ehrlich L, Meng F, et al. Inhibition of microRNA-24 increases liver fibrosis by enhanced menin expression in Mdr2-/- mice. J. Surg. Res. 2017

103. Vijayaraghavan J, Maggi EC, Crabtree JS. miR-24 regulates menin in the endocrine pancreas. Am. J. Physiol. Endocrinol. Metab. 2014; 307:E84-92. [PubMed: 24824656]

104. Marzioni M, Agostinelli L, Candelaresi C, et al. Activation of the developmental pathway neurogenin-3/microRNA-7a regulates cholangiocyte proliferation in response to injury. Hepatology. 2014; 60:1324-1335. [PubMed: 24925797]

105. Xiao Y, Wang J, Chen Y, et al. Up-regulation of miR-200b in biliary atresia patients accelerates proliferation and migration of hepatic stallate cells by activating PI3K/Akt signaling. Cell. Signal. 2014; 26:925-932. [PubMed: 24412919]

106. Shen W, Chen G, Dong R, et al. MicroRNA-21/PTEN/Akt axis in the fibrogenesis of biliary atresia. J. Pediatr. Surg. 2014; 49:1738-1741. [PubMed: 25487473]

107. Lee SO, Masyuk T, Splinter P, et al. MicroRNA15a modulates expression of the cell-cycle regulator Cdc25A and affects hepatic cystogenesis in a rat model of polycystic kidney disease. $\mathrm{J}$. Clin. Invest. 2008; 118:3714-3724. [PubMed: 18949056]

108. Glaser SS, Gaudio E, Miller T, et al. Cholangiocyte proliferation and liver fibrosis. Expert Rev. Mol. Med. 2009; 11:e7. [PubMed: 19239726]

109. Mancinelli R, Franchitto A, Glaser S, et al. GABA induces the differentiation of small into large cholangiocytes by activation of $\mathrm{Ca}(2+) / \mathrm{CaMK}$ I-dependent adenylyl cyclase 8 . Hepatology. 2013; 58:251-263. [PubMed: 23389926]

110. Alpini G, Glaser SS, Ueno Y, et al. Heterogeneity of the proliferative capacity of rat cholangiocytes after bile duct ligation. Am. J. Phys. 1998; 274:G767-75.

111. Glaser SS, Rodgers RE, Phinizy JL, et al. Gastrin inhibits secretin-induced ductal secretion by interaction with specific receptors on rat cholangiocytes. Am. J. Phys. 1997; 273:G1061-70.

112. Masyuk TV, Masyuk AI, Torres VE, et al. Octreotide inhibits hepatic cystogenesis in a rodent model of polycystic liver disease by reducing cholangiocyte adenosine $3^{\prime}, 5^{\prime}$-cyclic monophosphate. Gastroenterology. 2007; 132:1104-1116. [PubMed: 17383431]

113. Glaser S, Benedetti A, Marucci L, et al. Gastrin inhibits cholangiocyte growth in bile duct-ligated rats by interaction with cholecystokinin-B/Gastrin receptors via D-myo-inositol 1,4,5triphosphate-, $\mathrm{Ca}(2+)-$, and protein kinase $\mathrm{C}$ alpha-dependent mechanisms. Hepatology. 2000; 32:17-25. [PubMed: 10869284]

114. Marzioni M, Alpini G, Saccomanno S, et al. Glucagon-like peptide-1 and its receptor agonist exendin-4 modulate cholangiocyte adaptive response to cholestasis. Gastroenterology. 2007; 133:244-255. [PubMed: 17631146]

115. Marzioni M, Alpini G, Saccomanno S, et al. Exendin-4, a glucagon-like peptide 1 receptor agonist, protects cholangiocytes from apoptosis. Gut. 2009; 58:990-997. [PubMed: 18829977]

116. Alpini G, Glaser S, Robertson W, et al. Bile acids stimulate proliferative and secretory events in large but not small cholangiocytes. Am. J. Phys. 1997; 273:G518-29.

117. Alpini G, Glaser SS, Ueno Y, et al. Bile acid feeding induces cholangiocyte proliferation and secretion: evidence for bile acid-regulated ductal secretion. Gastroenterology. 1999; 116:179_ 186. [PubMed: 9869616]

118. Alpini G, Baiocchi L, Glaser S, et al. Ursodeoxycholate and tauroursodeoxycholate inhibit cholangiocyte growth and secretion of BDL rats through activation of PKC alpha. Hepatology. 2002; 35:1041-1052. [PubMed: 11981754]

119. Munoz-Garrido P, Marin JJ, Perugorria MJ, et al. Ursodeoxycholic acid inhibits hepatic cystogenesis in experimental models of polycystic liver disease. J. Hepatol. 2015; 63:952-961. [PubMed: 26044126] 
120. Gaudio E, Barbaro B, Alvaro D, et al. Vascular endothelial growth factor stimulates rat cholangiocyte proliferation via an autocrine mechanism. Gastroenterology. 2006; 130:12701282. [PubMed: 16618418]

121. Fabris L, Cadamuro M, Fiorotto R, et al. Effects of angiogenic factor overexpression by human and rodent cholangiocytes in polycystic liver diseases. Hepatology. 2006; 43:1001-1012. [PubMed: 16628643]

122. Marzioni M, Glaser S, Francis H, et al. Autocrine/paracrine regulation of the growth of the biliary tree by the neuroendocrine hormone serotonin. Gastroenterology. 2005; 128:121-137. [PubMed: 15633129]

123. Gigliozzi A, Alpini G, Baroni GS, et al. Nerve growth factor modulates the proliferative capacity of the intrahepatic biliary epithelium in experimental cholestasis. Gastroenterology. 2004; 127:1198-1209. [PubMed: 15480997]

124. LeSag EG, Alvaro D, Benedetti A, et al. Cholinergic system modulates growth, apoptosis, and secretion of cholangiocytes from bile duct-ligated rats. Gastroenterology. 1999; 117:191-199. [PubMed: 10381927]

125. Glaser S, Alvaro D, Francis H, et al. Adrenergic receptor agonists prevent bile duct injury induced by adrenergic denervation by increased cAMP levels and activation of Akt. Am. J. Physiol. Gastrointest. Liver Physiol. 2006; 290:G813-26. [PubMed: 16339297]

126. Glaser SS, Ueno Y, DeMorrow S, et al. Knockout of alpha-calcitonin gene-related peptide reduces cholangiocyte proliferation in bile duct ligated mice. Lab. Investig. 2007; 87:914-926. [PubMed: 17618297]

127. Francis H, Franchitto A, Ueno Y, et al. H3 histamine receptor agonist inhibits biliary growth of BDL rats by downregulation of the cAMP-dependent PKA/ERK1/2/ELK-1 pathway. Lab. Investig. 2007; 87:473-487. [PubMed: 17334413]

128. Alvaro D, Alpini G, Onori P, et al. Estrogens stimulate proliferation of intrahepatic biliary epithelium in rats. Gastroenterology. 2000; 119:1681-1691. [PubMed: 11113090]

129. Alvaro D, Onori P, Metalli VD, et al. Intracellular pathways mediating estrogen-induced cholangiocyte proliferation in the rat. Hepatology. 2002; 36:297-304. [PubMed: 12143037]

130. Svegliati-Baroni G, Ghiselli R, Marzioni M, et al. Estrogens maintain bile duct mass and reduce apoptosis after biliodigestive anastomosis in bile duct ligated rats. J. Hepatol. 2006; 44:11581166. [PubMed: 16481066]

131. Ray D, Han Y, Franchitto A, et al. Gonadotropin-releasing hormone stimulates biliary proliferation by paracrine/autocrine mechanisms. Am. J. Pathol. 2015; 185:1061-1072. [PubMed: 25794706]

132. Urribarri AD, Munoz-Garrido P, Perugorria MJ, et al. Inhibition of metalloprotease hyperactivity in cystic cholangiocytes halts the development of polycystic liver diseases. Gut. 2014; 63:16581667. [PubMed: 24436140]

133. Terada T, Nakanuma Y. Detection of apoptosis and expression of apoptosis-related proteins during human intrahepatic bile duct development. Am. J. Pathol. 1995; 146:67-74. [PubMed: 7531950]

134. Bhathal PS, Gall JA. Deletion of hyperplastic biliary epithelial cells by apoptosis following removal of the proliferative stimulus. Liver. 1985; 5:311-325. [PubMed: 4088005]

135. Kremer AE, Rust C, Eichhorn P, et al. Immune-mediated liver diseases: programmed cell death ligands and circulating apoptotic markers. Expert. Rev. Mol. Diagn. 2009; 9:139-156. [PubMed: 19298138]

136. Erickson N, Mohanty SK, Shivakumar P, et al. Temporal-spatial activation of apoptosis and epithelial injury in murine experimental biliary atresia. Hepatology. 2008; 47:1567-1577. [PubMed: 18393301]

137. Takeda K, Kojima Y, Ikejima K, et al. Death receptor 5 mediated-apoptosis contributes to cholestatic liver disease. Proc. Natl. Acad. Sci. U. S. A. 2008; 105:10895-10900. [PubMed: 18667695]

138. LeSage GD, Benedetti A, Glaser S, et al. Acute carbon tetrachloride feeding selectively damages large, but not small, cholangiocytes from normal rat liver. Hepatology. 1999; 29:307-319. [PubMed: 9918904] 
139. Marzioni M, LeSage GD, Glaser S, et al. Taurocholate prevents the loss of intrahepatic bile ducts due to vagotomy in bile duct-ligated rats. Am. J. Physiol. Gastrointest. Liver Physiol. 2003; 284:G837-52. [PubMed: 12684215]

140. Tabibian JH, O'Hara SP, Splinter PL, et al. Cholangiocyte senescence by way of N-ras activation is a characteristic of primary sclerosing cholangitis. Hepatology. 2014; 59:2263-2275. [PubMed: 24390753]

141. Sasaki M, Ikeda H, Yamaguchi J, et al. Bile ductular cells undergoing cellular senescence increase in chronic liver diseases along with fibrous progression. Am. J. Clin. Pathol. 2010; 133:212-223. [PubMed: 20093230]

142. Hayflick L. The limited in vitro lifetime of human diploid cell strains. Exp. Cell Res. 1965; 37:614-636. [PubMed: 14315085]

143. Campisi J, D'Adda di Fagagna F. Cellular senescence: when bad things happen to good cells. Nat. Rev. Mol. Cell Biol. 2007; 8:729-740. [PubMed: 17667954]

144. O'Hara SP, Splinter PL, Trussoni CE, et al. ETS proto-oncogene 1 transcriptionally up-regulates the cholangiocyte senescence-associated protein cyclin-dependent kinase inhibitor 2A. J. Biol. Chem. 2017; 292:4833-4846. [PubMed: 28184004]

145. McDaniel K, Meng F, Wu N, et al. Forkhead box A2 regulates biliary heterogeneity and senescence during cholestatic liver injury in micedouble dagger. Hepatology. 2017; 65:544-559. [PubMed: 27639079]

146. Coppe JP, Desprez PY, Krtolica A, et al. The senescence-associated secretory phenotype: the dark side of tumor suppression. Annu. Rev. Pathol. 2010; 5:99-118. [PubMed: 20078217]

147. Coppe JP, Patil CK, Rodier F, et al. Senescence-associated secretory phenotypes reveal cellnonautonomous functions of oncogenic RAS and the p53 tumor suppressor. PLoS Biol. 2008; 6:2853-2868. [PubMed: 19053174]

148. Aravinthan A. Cellular senescence: a hitchhiker's guide. Hum. Cell. 2015; 28:51-64. [PubMed: 25690721]

149. Sasaki M, Nakanuma Y. New concept: cellular senescence in pathophysiology of cholangiocarcinoma. Expert Rev. Gastroenterol. Hepatol. 2016; 10:625-638. [PubMed: 26680649]

150. Lesage G, Glaser SS, Gubba S, et al. Regrowth of the rat biliary tree after $70 \%$ partial hepatectomy is coupled to increased secretin-induced ductal secretion. Gastroenterology. 1996; 111:1633-1644. [PubMed: 8942744]

151. Lazaridis KN, Strazzabosco M, Larusso NF. The cholangiopathies: disorders of biliary epithelia. Gastroenterology. 2004; 127:1565-1577. [PubMed: 15521023]

152. Franchitto A, Onori P, Renzi A, et al. Recent advances on the mechanisms regulating cholangiocyte proliferation and the significance of the neuroendocrine regulation of cholangiocyte pathophysiology. Ann. Transl. Med. 2013; 1:27. [PubMed: 25332971]

153. Guicciardi ME, Gores GJ. Bile acid-mediated hepatocyte apoptosis and cholestatic liver disease. Dig. Liver Dis. 2002; 34:387-392. [PubMed: 12132783]

154. Gadd VL, Skoien R, Powell EE, et al. The portal inflammatory infiltrate and ductular reaction in human nonalcoholic fatty liver disease. Hepatology. 2014; 59:1393-1405. [PubMed: 24254368]

155. Priester S, Wise C, Glaser SS. Involvement of cholangiocyte proliferation in biliary fibrosis. World J. Gastrointest. Pathophysiol. 2010; 1:30-37. [PubMed: 21607140]

156. Williams MJ, Clouston AD, Forbes SJ. Links between hepatic fibrosis, ductular reaction, and progenitor cell expansion. Gastroenterology. 2014; 146:349-356. [PubMed: 24315991]

157. Fabris L, Strazzabosco M. Epithelial-mesenchymal interactions in biliary diseases. Semin. Liver Dis. 2011; 31:11-32. [PubMed: 21344348]

158. Fabris L, Brivio S, Cadamuro M, et al. Revisiting epithelial-to-mesenchymal transition in liver Fibrosis: clues for a better understanding of the "reactive" biliary epithelial phenotype. Stem Cells Int. 2016; 2016:2953727. [PubMed: 26880950]

159. Omenetti A, Bass LM, Anders RA, et al. Hedgehog activity, epithelial-mesenchymal transitions, and biliary dysmorphogenesis in biliary atresia. Hepatology. 2011; 53:1246-1258. [PubMed: 21480329] 
160. Taura K, Iwaisako K, Hatano E, et al. Controversies over the epithelial-to-mesenchymal transition in liver fibrosis. J. Clin. Med. 2016; 5

161. Omenetti A, Diehl AM. Hedgehog signaling in cholangiocytes. Curr. Opin. Gastroenterol. 2011; 27:268-275. [PubMed: 21423008]

162. Omenetti A, Porrello A, Jung Y, et al. Hedgehog signaling regulates epithelial-mesenchymal transition during biliary fibrosis in rodents and humans. J. Clin. Invest. 2008; 118:3331-3342. [PubMed: 18802480]

163. Omenetti A, Popov Y, Jung Y, et al. The hedgehog pathway regulates remodelling responses to biliary obstruction in rats. Gut. 2008; 57:1275-1282. [PubMed: 18375471]

164. Yokoyama T, Komori A, Nakamura M, et al. Human intrahepatic biliary epithelial cells function in innate immunity by producing IL-6 and IL-8 via the TLR4-NF-kappaB and -MAPK signaling pathways. Liver Int. 2006; 26:467-476. [PubMed: 16629651]

165. Yasoshima M, Kono N, Sugawara H, et al. Increased expression of interleukin- 6 and tumor necrosis factor-alpha in pathologic biliary epithelial cells: in situ and culture study. Lab. Investig. 1998; 78:89-100. [PubMed: 9461125]

166. Grappone C, Pinzani M, Parola M, et al. Expression of platelet-derived growth factor in newly formed cholangiocytes during experimental biliary fibrosis in rats. J. Hepatol. 1999; 31:100-109. [PubMed: 10424289]

167. Rockey DC, Fouassier L, Chung JJ, et al. Cellular localization of endothelin-1 and increased production in liver injury in the rat: potential for autocrine and paracrine effects on stellate cells. Hepatology. 1998; 27:472-480. [PubMed: 9462646]

168. Saperstein LA, Jirtle RL, Farouk M, et al. Transforming growth factor-beta 1 and mannose 6phosphate/insulin-like growth factor-II receptor expression during intrahepatic bile duct hyperplasia and biliary fibrosis in the rat. Hepatology. 1994; 19:412-417. [PubMed: 8294098]

169. Spirli C, Fabris L, Duner E, et al. Cytokine-stimulated nitric oxide production inhibits adenylyl cyclase and cAMP-dependent secretion in cholangiocytes. Gastroenterology. 2003; 124:737-753. [PubMed: 12612912]

170. Savard CE, Blinman TA, Choi HS, et al. Expression of cytokine and chemokine mRNA and secretion of tumor necrosis factor-alpha by gallbladder epithelial cells: response to bacterial lipopolysaccharides. BMC Gastroenterol. 2002; 2:23. [PubMed: 12377103]

171. Tabibian JH, Varghese C, LaRusso NF, et al. The enteric microbiome in hepatobiliary health and disease. Liver Int. 2016; 36:480-487. [PubMed: 26561779]

172. Yang L, Seki E. Toll-like receptors in liver fibrosis: cellular crosstalk and mechanisms. Front. Physiol. 2012; 3:138. [PubMed: 22661952]

173. Maroni L, Agostinelli L, Saccomanno S, et al. Nlrp3 activation induces Il-18 synthesis and affects the epithelial barrier function in reactive cholangiocytes. Am. J. Pathol. 2017; 187:366-376. [PubMed: 27912077]

174. Trussoni CE, Tabibian JH, Splinter PL, et al. Lipopolysaccharide (LPS)-induced biliary epithelial cell NRas activation requires epidermal growth factor receptor (EGFR). PLoS One. 2015; 10:e125793. [PubMed: 25915403] 


\section{Highlights}

- Cholangiocytes are heterogeneous epithelial cells whose highly specialized functions is largely dependent on their size (e.g., small vs. large cholangiocytes).

- $\quad$ Small and large cholangiocytes possess unique cellular ultrastructure and polarized membrane proteins that allow different responses in both homeostatic conditions as well as in injury.

- Upon injury, reactive cholangiocytes develop a neuroendocrine phenotype and are capable of autocrine and paracrine signaling to maintain homeostasis or adopt proinflammatory responses. These responses can also be mediated by microRNA in both healthy and diseased states.

- Cholangiocytes can also undergo senescence (cell cycle arrest), thus avoiding neoplastic transformation, however this status can also potential disease development via hypersecretion of proinflammatory cytokine and chemokines (termed senescence-associated secretory phenotype [SASP]). 


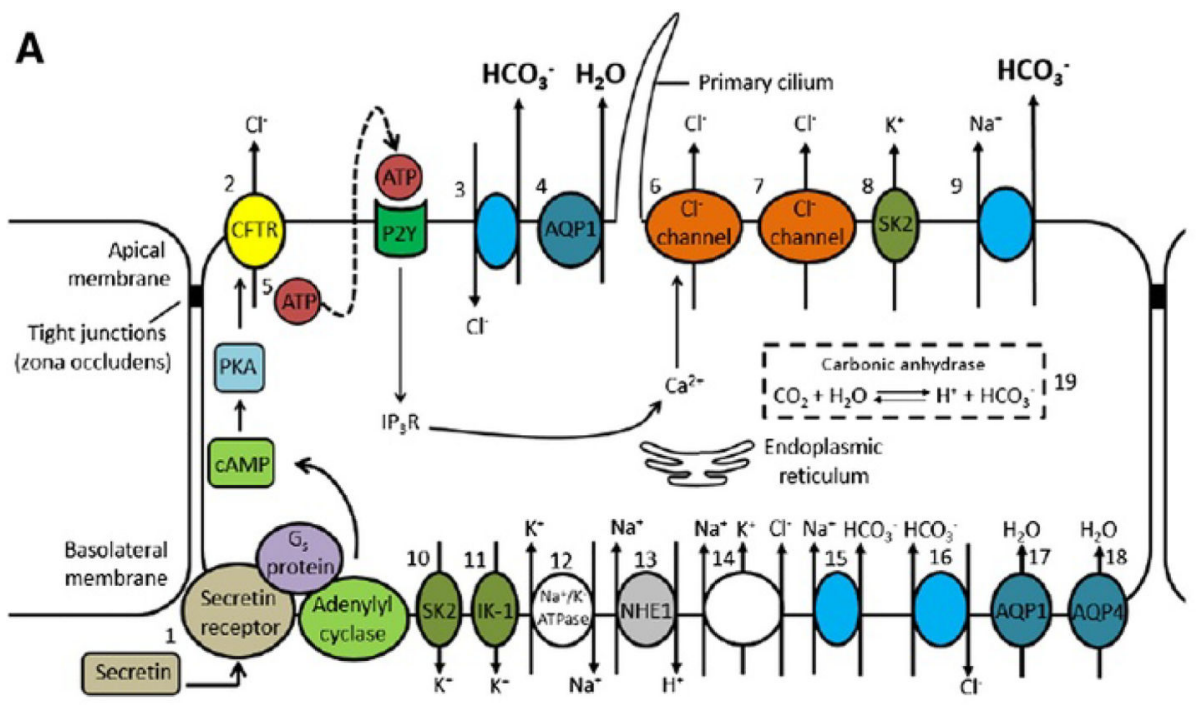

B

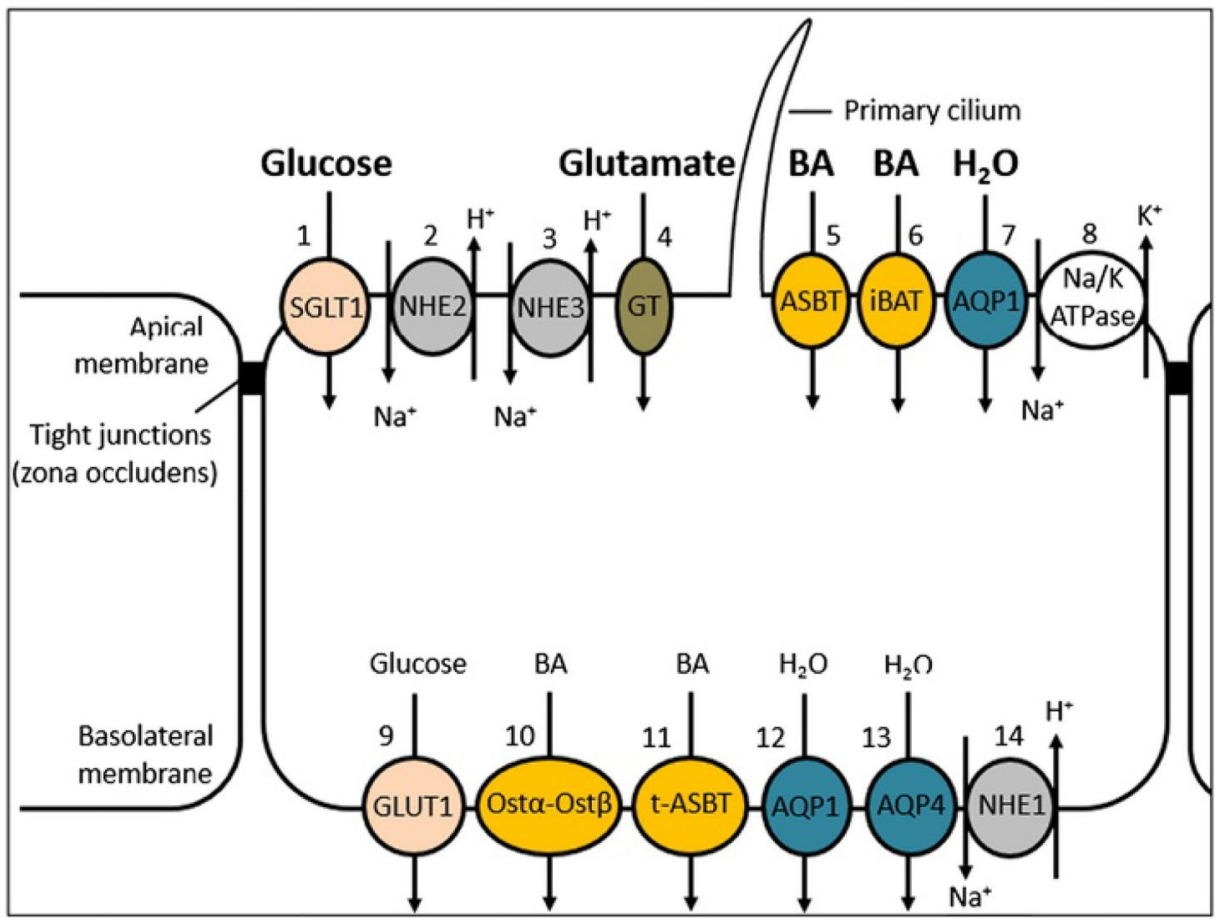

Fig. 1.

A. Cholangiocyte secretory functions. The most widely accepted model of ductal bile formation involves [1] secretin activation of the cAMP-PKA signaling pathway, which then leads to [2] activation of CFTR, causing extrusion of $\mathrm{Cl}^{-}$. This then stimulates the [3] $\mathrm{Cl}$ ${ }^{-} / \mathrm{HCO}_{3}{ }^{-}$exchanger which secretes $\mathrm{HCO}_{3}{ }^{-}$and creates an osmotic gradient that leads to the [4] passive movement of water across AQP1. More recently, an alternative hypothesis suggests that [5] activation of CFTR leads to the release of ATP, which then phosphorylates $\mathrm{IP}_{3} \mathrm{R}$ on the endoplasmic reticulum. This causes the release of $\mathrm{Cl}^{-}$via the [6] $\mathrm{Ca}^{2+}$ dependent $\mathrm{Cl}^{-}$channel, which creates a gradient leading to [3] activation of the $\mathrm{Cl}^{-} / \mathrm{HCO}_{3}^{-}$ 
exchanger. $\mathrm{Ca}^{2+}$ is also transported via a [7] $\mathrm{Ca}^{2+}$ - and cAMP-independent $\mathrm{Cl}^{-}$channel. Finally, the apical membrane also contains [8] $\mathrm{K}^{+}$channels (SK2 and IK-1) and a [9] $\mathrm{Na}^{+}-$ $\mathrm{HCO}_{3}{ }^{-}$cotransporter (mice). On the basolateral domain, there are two types of $\mathrm{K}^{+}$channels: [10] SK2 and [11] IK-1. There is also [12] a Na $/ \mathrm{K}^{-}$ATPase, [13] a $\mathrm{Na}^{+} / \mathrm{H}^{+}$exchanger (NHE1), [14] a Na $/ \mathrm{K}^{+} / \mathrm{Cl}^{-}$cotransporter, [15] a Na $/ \mathrm{HCO}_{3}{ }^{+}$cotransporter (rats), [16] a $\mathrm{Na}$ ${ }^{+}$-dependent $\mathrm{Cl}^{-} / \mathrm{HCO}^{-}$exchanger (humans), and water channels, [17] AQP1 and [18] AQP4. Within the cell, [19] carbonic anhydrase allows for the production of $\mathrm{HCO}_{3}{ }^{-}$. Abbreviations: ATP, adenosine triphosphate; AQP, aquaporin; cAMP, cyclic adenosine monophosphate; CFTR, cystic fibrosis transmembrane conductance regulator; IK-1, intermediate-conductance $\mathrm{K}+$ channel; PKA, protein kinase A; $\mathrm{NHE}, \mathrm{Na}^{+} / \mathrm{H}^{+}$exchanger; SK2, small conductance $\mathrm{K}^{+}$channel.

B. Cholangiocyte absorptive functions. Cholangiocytes have a number of transporters that allow the absorption of a variety of molecules [1]. Glucose is absorbed through SGLT1, $\mathrm{Na}^{+}$ is absorbed through [2] NHE2 and [3] NHE3, glutamate is absorbed through a glumate transporter, bile acids are absorbed through [5] ASBT and [6] iBAT and [7] water is absorbed through AQP1. On the basolateral membrane, [8] glucose is transported via GLUT1, bile is transported via [9] Osta-Ost $\beta$ and [10] t-ASBT, water is transported via [11] AQP1 and [12] AQP4. Lastly, the basolateral membrane contains a [13] $\mathrm{Na}^{+} / \mathrm{H}^{+}$exchanger (NHE3). Abbreviations: ASBT, apical sodium-dependent bile acid transporter; AQP, aquaporin; BA, bile acids; GLUT, glucose transporter; GT, glutamate transporter; iBAT, ileal bile acid transporter; NHE, $\mathrm{Na}^{+} / \mathrm{H}^{+}$exchanger; OST, organic solute transporter alpha; SGLT, $\mathrm{Na}^{+}$-Glucose cotransporter.

Biochim Biophys Acta. Author manuscript; available in PMC 2018 July 01. 


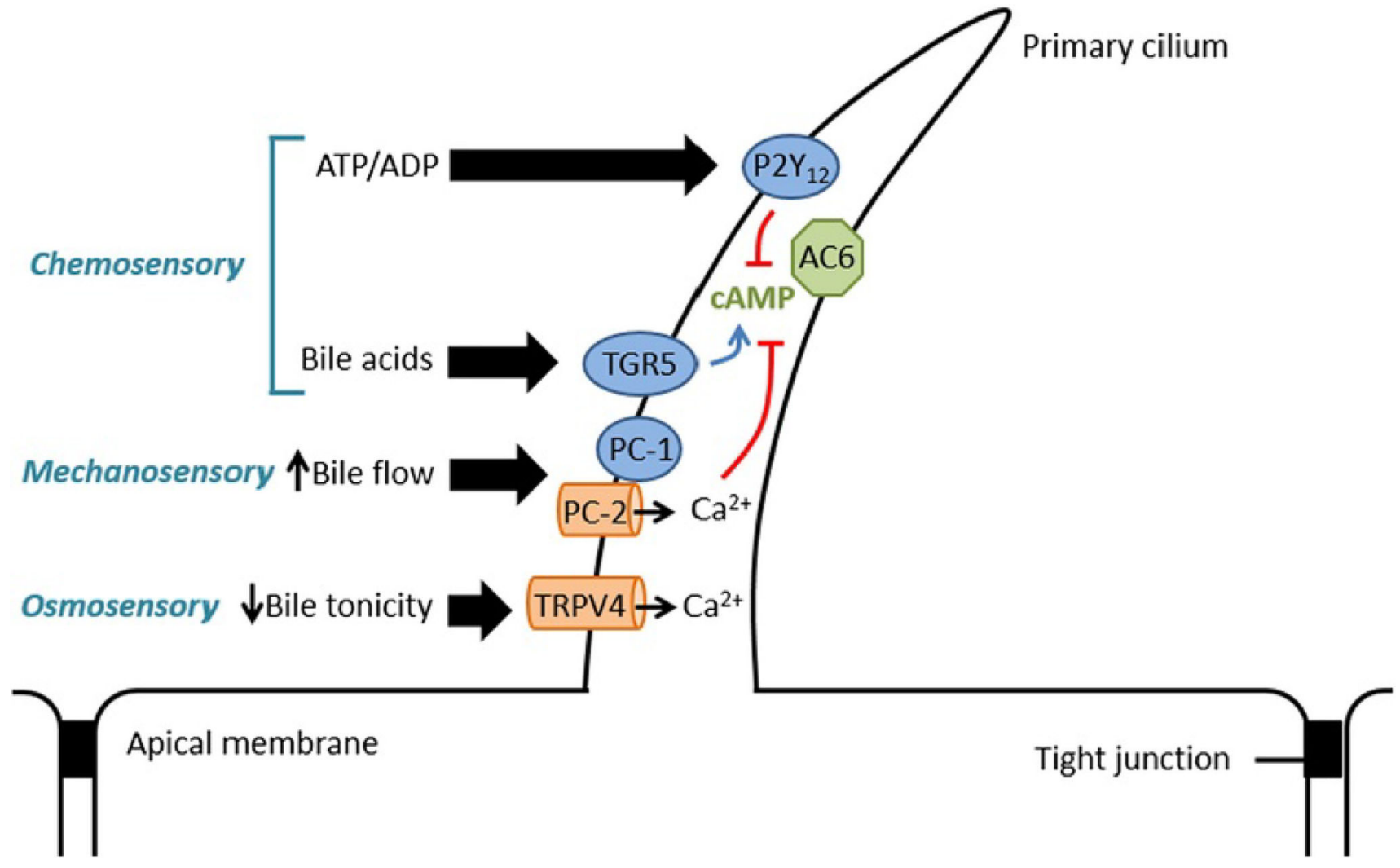

Fig. 2.

Functions of primary cholangiocyte cilium. Cholangiocyte cilia have mechano-, chemo- and osmosensory functions. This figure depicts the ciliary pathways involved in inhibiting cholangiocyte secretion, but the inverse relationships also allow for cholangiocyte secretion (e.g., decreased bile flow, increased bile tonicity etc.). 1) Chemosensory: ATP/ADP and bile acids can lead to inhibition of cholangiocyte secretion through the $\mathrm{P}_{2} \mathrm{Y}_{12}$ and TGR5 receptors respectively. The activation of $\mathrm{P}_{2} \mathrm{Y}_{12}$ leads to the inhibition of AC6 which causes decreased cAMP production, thereby causing a reduction in the efflux of $\mathrm{Cl}^{-}$, which in turn leads to decreased $\mathrm{HCO}_{3}{ }^{-}$secretion. Activation of TGR5 by bile acids leads to an increase in cAMP-mediated cholangiocyte secretion. 2) Mechanosensory: An increase in bile flow activates the PC-1/PC-2 complex, which is comprised of a mechanoreceptor (PC-1) and a $\mathrm{Ca}^{2+}$ channel (PC-2). This leads to an increase in intracellular $\mathrm{Ca}^{2+}$ and inhibition of cAMPinduced biliary secretion. 3) Osmosensory: A decreased in bile tonicity leads to an influx of $\mathrm{Ca}^{2+}$, which again causes a decrease in cAMP-induced biliary secretion. Abbreviations: AC6, adenylyl cyclase 6; ADP, adenosine diphosphate; ATP, adenosine riphosphate; cAMP, cyclic adenosine monophosphate; PC-1, polycystin-1 ; PC-2, polycystin-2; TRPV4, transient receptor potential channel vanilloid subfamily 4. 


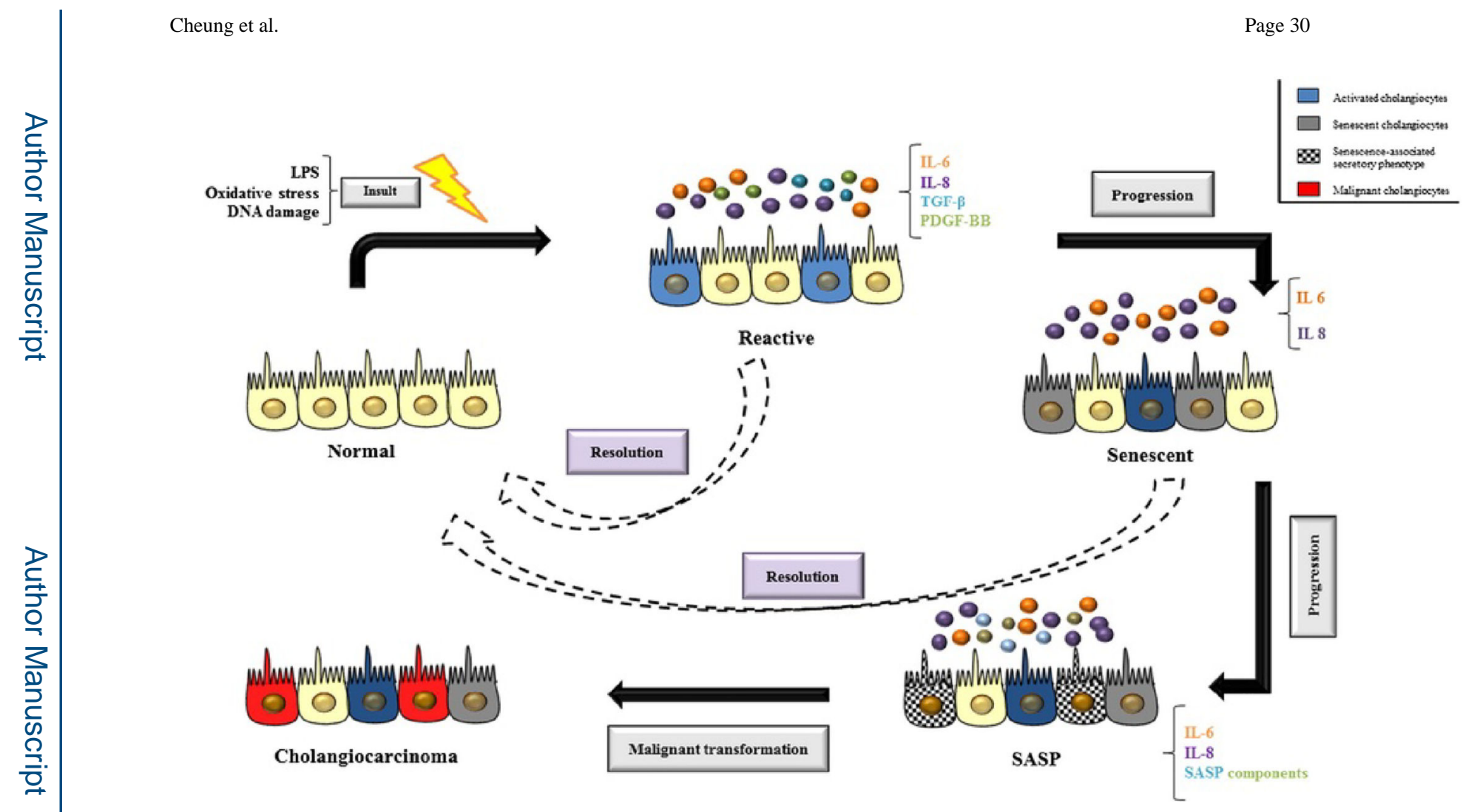

Fig. 3.

Schematic representation of cholangiocyte plasticity. Endogenous and exogenous insults can activate normal cholangiocytes which are characterized by enhanced secretion of proinflammatory cytokines and growth factors that recruit both immune and mesenchymal cells to promote biliary remodeling. After insults, proliferation is also activated as a consequence of cholangiocyte death (lysis and/or apoptosis) and if the cellular injury continues, cholangiocytes can become senescent. Senescent cholangiocytes are under permanent cell cycle arrest and apoptosis resistant. Ongoing cellular injury leads to continuous generation of senescent cells leading to progression into a senescence-associated secretory phenotype. This eventually leads to tissue dysfunction and tumor promotion. The dashed arrows suggest that reactive and senescent cholangiocytes can go through repair mechanisms that are mediated by several pathways, with Hedgehog (Hh) signaling pathway being one of the most important. Abbreviations: IL, interleukin; LPS, lipopolysaccharide; PDGF-BB, platelet-derived growth factor-BB; SASP, senescence-associated secretory phenotype; TGF$\beta$, transforming growth factor $\beta$. 


\section{Table 1}

\section{Classification of cholangiopathies.}

\begin{tabular}{|l|}
\hline Genetic \\
\hline Alagille's syndrome \\
\hline Caroli's syndrome \\
\hline Cystic fibrosis \\
\hline MDR3 deficiency \\
\hline Polycystic liver disease (ADPLD, ADPKD, ARPKD) \\
\hline Immune-mediated \\
\hline Acute allograft rejection \\
\hline Chronic allograft rejection \\
\hline Graft versus host disease \\
\hline Primary biliary cholangitis \\
\hline Idiopathic \\
\hline Biliary atresia \\
\hline Idiopathic childhood/adulthood ductopenia \\
\hline IgG4 cholangiopathy \\
\hline Primary sclerosing cholangitis \\
\hline Sarcoidosis \\
\hline Infectious \\
\hline AIDS cholangiopathy (e.g., viral cholangitis) \\
\hline Bacterial cholangitis (e.g., Escherichia coli, Klebsiella, Enterococcus, Enterobacter, Pseudomonas, anaerobes) \\
\hline Parasitic cholangitis (e.g., Ascaris lumbricoides, Opisthorchis viverrini, Clonorchis sinensis, Fasciola hepatica) \\
\hline Malignant \\
\hline Cholangiocarcinoma \\
\hline Other \\
\hline Drug-induced (e.g., Floxuridine-induced cholangiopathy, ketamine cholangiopathy) \\
\hline Vascular/ischemic (e.g., post-liver transplant hepatic artery stenosis, systemic vasculitis) \\
\hline
\end{tabular}

Abbreviations: ADPKD, autosomal dominant polycystic kidney disease; ADPLD, autosomal dominant polycystic liver disease; AIDS, acquired immunodeficiency syndrome; ARPKD, autosomal recessive polycystic kidney disease; IgG4, immunoglobulin G subclass 4; MDR3, multidrug resistance 3. 
Table 2

Known differences between small and large cholangiocytes.

\begin{tabular}{|c|c|c|}
\hline Phenotype & Small cholangiocytes & Large cholangiocytes \\
\hline Location & Smaller bile ducts & Larger bile ducts \\
\hline Shape & Cuboidal & Columnar \\
\hline \multirow[t]{2}{*}{ Intracellular structures } & High nucleus to cytoplasm ratio & Low nucleus to cytoplasm ratio \\
\hline & $\begin{array}{l}\text { Multilobulated nucleus, few mitochondria, abundant Golgi } \\
\text { apparatus, minimal rough endoplasmic reticulum }\end{array}$ & $\begin{array}{l}\text { Multilobulated nucleus, few mitochondria, abundant } \\
\text { Golgi apparatus, more rough endoplasmic reticulum }\end{array}$ \\
\hline Apical surface & $\begin{array}{l}\text { Lysosomes and vesicles localized to the apical membrane, } \\
\text { tight junctions between cells, coated pits, microvilli }\end{array}$ & $\begin{array}{l}\text { Lysosomes and vesicles localized to the apical } \\
\text { membrane, tight junctions between cells, coated pits, } \\
\text { microvilli }\end{array}$ \\
\hline \multirow[t]{6}{*}{ Protein expression } & Express lipase, a-amylase and trypsin & Express lipase, $a$-amylase and trypsin \\
\hline & AE1 absent, AE2 present & AE1 absent, AE2 present \\
\hline & CFTR absent & CFTR present \\
\hline & CYP4502E1 absent & CYP4502E1 present \\
\hline & Blood group antigens present (e.g., A, B, O, Lewis) & Blood group antigens absent \\
\hline & Bcl-2 present & Bcl-2 absent \\
\hline \multirow[t]{2}{*}{ Response to injury } & Resistant to liver injury & Susceptible to liver injury \\
\hline & Can proliferate (e.g., behave as liver progenitor cells) & \\
\hline
\end{tabular}

Abbreviations: AE2, anion exchanger 2; Bcl-2, B-cell lymphoma 2; CFTR, cystic fibrosis transmembrane conductance regulator. 
Table 3

Factors that stimulate or inhibit cholangiocyte proliferation.

\begin{tabular}{|c|c|c|}
\hline Class & Known stimulators of proliferation & Known inhibitors of proliferation \\
\hline \multirow[t]{2}{*}{ Gastrointestinal hormones } & Glucagon-like peptide 1 (GLP1) & Somatostatin \\
\hline & Exendin-4 (GLP1 receptor agonist) & Gastrin \\
\hline \multirow[t]{2}{*}{ Bile acids } & Taurocholate (large cholangiocytes only) & Ursodeoxycholic acid (all cholangiocytes) \\
\hline & Taurolithocholic acid (large cholangiocytes only) & Tauroursodeoxycholate (all cholangiocytes) \\
\hline \multirow[t]{3}{*}{ Angiogenic factors } & Vascular endothelial growth factor & \\
\hline & Angiopoietin-1 & \\
\hline & Angiopoietin-2 & \\
\hline \multirow[t]{5}{*}{ Neuropeptides and neurotransmitters } & Serotonin Nerve growth factor & \\
\hline & Parasympathetic innervation & \\
\hline & Sympathetic innervation & \\
\hline & Alpha-calcitonin & \\
\hline & Histamine & \\
\hline \multirow[t]{2}{*}{ Hormones } & $17-\beta$-estradiol & \\
\hline & Gonadotropin releasing hormone (GnRH) & \\
\hline Other & Matrix metalloproteinases (MMP) & \\
\hline
\end{tabular}


Table 4

Role of miRNAs in cholangiocyte homeostasis and in cholangiopathies.

\begin{tabular}{|c|c|c|c|c|}
\hline Cohort & miRNA & $\begin{array}{l}\text { Direction of } \\
\text { effect }^{a}\end{array}$ & $\begin{array}{l}\text { Affected } \\
\text { mRNA }\end{array}$ & Outcome of miRNA changes \\
\hline \multirow[t]{7}{*}{ Healthy } & miR-33a & - & ABCA1, ABCG1 & Maintains cellular cholesterol efflux \\
\hline & & - & $\mathrm{ABCB} 11$ & $\begin{array}{l}\text { Maintains homeostatic BSEP expression for bile } \\
\text { acid export into bile canaliculi }\end{array}$ \\
\hline & & - & ATP8B1 & $\begin{array}{l}\text { Maintains membrane polarity and secretory } \\
\text { function }\end{array}$ \\
\hline & miR-144 & - & ABCA1 & Maintains plasma HDL levels \\
\hline & miR-122, miR-422a & - & CYP7A1 & Maintains homeostatic bile acid synthesis \\
\hline & miR-98, let-7 & - & CIS & Suppression of CIS may indirectly suppress NF- $k \beta$ \\
\hline & miR-513 & - & B7-H1 & $\begin{array}{l}\text { Decrease in IFN- } \gamma \text { induced B7-H1 expression } \\
\text { (which has dual functions in T cell regulation) }\end{array}$ \\
\hline $\begin{array}{l}\text { Experimental bliary } \\
\text { obstruction (BDL } \\
\text { mice) }\end{array}$ & $\operatorname{miR}-21$ & Upregulated & Smad-7 & Bile duct proliferation and fibrosis \\
\hline $\begin{array}{l}\text { Experimental } \\
\text { sclerosing cholangitis } \\
\text { (Mdr2-/- mice) }\end{array}$ & $\operatorname{miR}-24$ & Downregulated & MEN1 & Limits expression of fibrosis \\
\hline $\begin{array}{l}\text { Experimental } \\
\text { sclerosing cholangitis } \\
\text { (BDL and DDC fed } \\
\text { mice) }\end{array}$ & miR-7-a-1, miR-7-a-2 & Upregulated & Ngn-3 & $\begin{array}{l}\text { Inhibits promitotic effect of Ngn-3, thus decreasing } \\
\text { cholangiocyte proliferation and collagen deposition }\end{array}$ \\
\hline PBC & miR-506 & Upregulated & AE2 & $\begin{array}{l}\text { Decreased AE2 expression leads to impaired } \\
\text { biliary secretion }\end{array}$ \\
\hline \multirow[t]{2}{*}{ Biliary atresia } & $\mathrm{miR}-200 \mathrm{~b}$ & Upregulated & FOG2 & $\begin{array}{l}\text { Increased PI3K/AKT signalling, leading to HSC } \\
\text { cell growth and migration with increased fibrosis }\end{array}$ \\
\hline & $\operatorname{miR}-21$ & Upregulated & PTEN & $\begin{array}{l}\text { Increased AKT signalling, leading to HSC cell } \\
\text { growth and migration with increased fibrosis }\end{array}$ \\
\hline PCK rat & $\mathrm{miR}-15 \mathrm{a}$ & Downregulated & $\operatorname{Cdc} 25 \mathrm{~A}$ & $\begin{array}{l}\text { Cell cycle progression and cyst expansion in } \\
\text { normal rat cholangiocytes }\end{array}$ \\
\hline
\end{tabular}

Abbreviations: AE2, anion exchanger2; BDL, bile-duct ligation; BSEP, bile salt exporter protein; Cdc25A, cell division cycle 25A; CIS, cytokineinducible Src homology 2-containing protein; DDC, 3,5; diethoxycabonyl-1,4-dihydrocollidine; FOG2, friend of GATA 2; HDL, high density lipoprotein; IFN, interferon; NF- $\kappa \beta$; nuclear factor kappa-light-chain enhancer of activated B cells; Ngn-3, neurogenin-3; PBC, primary biliary cholangitis; PCK, polycystic rat; PI3K, phosphoinositide 3-kinase; PSC, primary sclerosing cholangitis; PTEN, phosphatase and tensin homolog; Smad; small mothers against decapentaplegic.

a No direction of effect is listed for miRNA described in homeostatic circumstances (e.g., "healthy") as the listed direction of effect is relative to controls. miRNAs are inherently inhibitory; that is, they inhibit their target mRNAs. 